SLOVO, sv. 71 (2021), 27-56, Zagreb 2020.

Искра ХРИСТОВА-ШОМОВА

Софийски университет »Св. Климент Охридски« София

iskrashomova@gmail.com
UDK 27-243.6:811.163.42’255

272-282.7:003.349.1

Izvorni znanstveni članak

Primljen: 24. travnja 2019.

Prihvaćen: 30. listopada 2020.

\title{
ПРИТЧИ СОЛОМОНОВИ ВЪВ ВТОРИЯ БЕРАМСКИ БРЕВИАР
}

В статията са разгледани две четива от Притчи Соломонови (1,1-9 и 3,13-20), поместени във Втория берамски бревиар, в съпоставка с три глаголически и три кирилски средновековни източника: Първи Връбнички бревиар от XII-XIII в., Хървоев мисал от началото на XV в., Чешка глаголическа библия от 1416 г., Григоровичев паримейник от XII в., ръкопис от РНБ F.I.461 от XIV в., Острожка библия от 1591 г. От сравнението се вижда, че между гръцкия и латинския текст на тези четива има разлики както на синтактично, така и на лексикално равнище. В първото четиво двата хърватски бревиара най-често следват синтаксиса на латинския текст, като запазват лексиката от ранния (Кирило-Методиев) превод от гръцки. Във второто четиво между двата хърватски бревиара има повече и по-значителни разлики. Първият връбнички бревиар сдържа стария превод от гръцки почти без промени и съвпада с кирилските източници, а във Втория берамски бревиар и Хървоевия мисал текстьт съответства на латинския синтактично и по дължина, но в повечето случаи се пази старата Кирило-Методиева лексика. Прави впечатление голямата текстова близост между двата хърватски паметника (Втория берамски бревиар и Хървоевия мисал). Трите кирилски текста съвпадат почти напълно и очевидно възхождат към един и същ древен превод (Кирило-Методиевия). Чешкият превод следва латинския текст, като в него се използват редица типично чешки лексеми (opatrnost, robat, zprava, počatek, bazen, blazen, nahrdlek, nalezenie, prodlenie, pravica, levica, cesta, pokoine).

Ключови думи: Притчи, Бревиар, Мисал, Библия, превод, редакция.

\section{1. УВОД}

Вторият берамски бревиар се състои от два тома, които се пазят в Университетската библиотека в Любляна под обща сигнатура Ms 163. Ръкописът е писан през XV в. с хърватска глаголица. Първият том съ- 
държа Proprium de tempore, 264 листа пергамент, а вторият том съдържа Proprium Sanctorum, 176 листа пергамент (VAJS 1910: XVI-XX; Drugi beramski brevijar 2018).

Тук ще бъдат разгледани две четива от Притчи Соломонови, които се намират в първия том. Тази библейска книга е подходяща, защото голяма част от нея е включена в състава на Паримейника. Изследванията показват, че пълният чети текст е съставен въз основа на превода в Паримейника, като липсващите части са допълнени (THOMSON 1998: 832; ALEKSEEV 1999: 156). Може да се предполага, че преводът на Паримейника е Кирило-Методиев или Методиев, а преводът на пълния текст също с голяма вероятност се отнася към запазените преводи на св. Методий (ALEKSEEV 1999: 198).

Освен това преводьт на първите три глави от Притчи Соломонови в хърватските глаголически бревиари е представен от Йозеф Вайс (VAJS 1910: 38-70). Той посочва, че преводът е направен от гръцки и публикува текста в Първия връбнички бревиар успоредно с грьцкия текст по Септуагинта. В подробни бележки към всеки библейски стих е коментниран преводът и е направено сравнение с още няколко бревиара: Бревиара на Вид Омишлянин, Пашманския, Първи и Втори новлянски и Ватиканския Illir. Borg. 5. За сравнение е привлечена и кирилската традиция въз основа на Григоровичевия паримейник по изданието на Брант (BRANDT 1894). Вайс посочва, че хърватските глаголически бревиари се разделят на две групи според текста на Притчи: в едната преводът е от гръцки и отразява първия славянски (Кирило-Методиевия) превод, а в другата преводът е от латински. Текстьт в ръкописите с превод от гръцки обаче не е еднакъв, защото и в тях има поправки въз основа на латинския текст по Вулгата, а същевременно върху превода от латински оказва влияние по-ранният превод от гръцки: »V textech hlaholských lze pozorovati dvě skupiny překladu: starší a lepší překlad přejatý z původního překladu staroslověnského, vzdělaný na předloze řecké, byt' tu a tam, zejména na počátku opravovaný a upravený podle latinské Vulgáty, a vedle něho pozdější překlad, pořízený asi již na území chrvatském podle předlohy latinské, ale tak, že překladatel měl po ruce i starší překlad, do něhož nahlížel« (VAJS 1910: 39). Въз основа на съпоставката между хърватските бревиари Вайс отбелязва също, че най-добре запазеният текст на първичния превод от грьцки се пази в Първи връбнички бревиар и в Бревиара на Вид Омишлянин. От разночетенията, които привежда Вайс, се вижда, че бревиарите, които той е използвал, се разделят на две групи: в едната текстьт се придържа 
в голяма степен към гръцкия, въпреки че има внесени и промени за сближаване с латинския, а в другата текстът е редактиран в по-голяма степен в посока към изравняване с латинския. В първата група влизат Първият връбнички, Бревиарът на Вид Омишлянин и Пашманският, а във втората - Първи и Втори новлянски и Ватиканският Illir. Borg. 5.

По-нататьк Вацлав Чермак продължава изследването на текста на Притчи Соломонови в хърватските глаголически бревиари (С̆ЕRMÁK 1999; 2003; 2007). Той сыщо ги разделя на две групи (А и В) според това дали текстът е преведен от гръцки или от латински. Въз основа на съпоставката между текстовете в група А той я разделя на две подгрупи $\left(\mathrm{A}_{1}\right.$ и $\left.\mathrm{A}_{2}\right)$ според степента на влияние на латинския текст. Чермак посочва също, че в текстовете от група В се срещат лексеми, които съответстват на гръцкия текст, но не се откриват в ръкописите от група $\mathrm{A}_{1}$. Това според него означава, че е съществувал по-ранен хърватски източник, който е съдържал текст, по-близък до гръцкия от текстовете на всички запазени бревиари: »Památki skupiny B však mají doloženy některé lekce závislé na řecké předloze, jež nenacházíme $\mathrm{v}$ rukopisech skupiny $\mathrm{A}_{1}$, což vede $\mathrm{k}$ předpokladu, že opisovači měli k dispozici bezesporu obsáhlejší a kvalitnější slovanskou verzi, než jak by bylo možno soudit jen na základě délky čtení Breviaře Vita z Omišlje, který je obvykle považován za codex optimus pro starozákonní texty charvatskohlaholských breviař̀i« (ČERMÁK 2003:65).

Чермак публикува и наблюдения върху превода на Притчи Соломонови в Първи връбнички и Втори новлянски бревиар в съпоставка с кирилските паримейници (Григоровичев, Лобковски и Захарински). Неговото изследване показва, че текстьт в Първи връбнички бревиар е по-близък до гръцкия отколкото до латинския текст и до голяма степен съвпада с текста в кирилските паримейници, докато текстьт във Втория новлянски бревиар показва по-голяма близост до латинския текст. Важно е неговото наблюдение, че на местата, които не влизат в Паримейника, Втори новлянски бревиар съдържа текст, който съответства на гръцкия (С̆ERMÁK 1999).

Йоханес Райнхарт изследва текста на книгите с премъдрости (в тях той включва Притчи Соломонови, Премъдрост Соломонова, Исус бен Сирах и Песен на песните) в хърватските глаголически мисали, като за основен текст използва мисала Vat. Illir. Borg. 4 (писан между 1317 и 1323 г.), но разглежда варианти и по други мисали, включително и Хървоевия. В мисалите са включени 34 четива от изброените библейски книги. Наблюденията на Райнхарт показват, че по-голямата част от текста на тези четива в мисалите съответства на латинския текст, но на отделни места 
има стихве, които съответстват на гръцкия текст, като в някои случаи съвпадат с Паримейника, а в други случаи се различават от него. Той отбелязва: »First of all, and not unexpectedly, we see that the bulk of the texts goes back to the Latin Vulgate. Only in a few cases can the traces of an older translation from the Greek be located. Most of them correspond to the translation preserved in the Pareomiary, even when the text is missing in the breviary. This suggests either that Pareomiary texts must have been extant in Croatia outside the breviary or that the missal was compiled very early (the second possibility is less probable)« (REINHART 1986: 82). Някои от тези стихове, в които личи превод от гръцки, влизат във второто четиво, разгледано тук. По-нататък изследователят се спира на тези редки случаи, при които текстьт в мисалите съответства на гръцкия, но се различава от текстовете и на Паримейника, и на Бревиара. Той поставя въпроса дали не може да се предполага, че в тези случаи е отразен друг древен превод, различен от паримейния, може би Методиев (цялата статия е написана с оглед на това да бъде изследвана възможността да се открият доказателства за запазен пълен Методиев библейски превод). Но отбелязва, че тези примери са твърде малобройни, за да може от тях да се достигне до такъв генерален извод: »However, I would seriously hesitate to conjecture a full Cyrillo-Methodian Bible translation on the basis of these very limited data.« (REINHART 1986: 82). Според мене в тези случаи става дума за промени в текста, внесени от хърватските книжовници, каквито се откриват и в разгледаните по-долу четива.

Докато работех върху транслитерацията за подготовката на електронното издание на Втория берамски бревиар, ми направи впечатление, че текстът на библейските четива в него на места се придържа към ранния (Кирило-Методиев) превод и следва гръцкия текст, а на места съответства на латинския. Публикацията на Вайс дава възможност, да се сравни текстьт на Втория берамски бревиар с текста на Първия връбнички бревиар и на останалите източници, използвани от Вайс, и да се определи неговото място сред хърватските глаголически бревиари. В сравнението е включен още един хърватски глаголически източник, Хървоевият мисал с разночетенията, дадени в изданието му, а също Чешката глаголическа Библия. Използвани са и три кирилски източника: Григоровичев паримейник, ръкопис от РНБ F.I.461 и Острожката библия.

Давам двете четива на гръцки (по Септуагинта) и на латински (по Вулгата) и според използваните славянски източници ${ }^{1}$ и коментирам раз-

1 Транслитерацията на глаголическите текстове е според изданията, в които са публикувани, затова някои глаголически букви в различните текстове, транслитерирани 
ликите между текстовете. Четивата са дадени в Приложение 1 и Приложение 2.

\section{2. ПРИТЧИ СОЛОМОНОВИ 1,1-9}

Сравнението между текстовете показва най-напред, че между гръцкия текст в Септуагинта и латинския текст във Вулгата има доста разлики. Повечето от тях вероятно се дължат на това, че преводът в Септуагинта е доста свободен. Разликите между двата хърватски бревиара не са многобройни и не са съществени. И в двата се забелязва една и съща тенденция към изравняване с латинския текст на синтактично равнище, но запазване на лексиката от първоначалния превод. Трите кирилски текста съдържат един и същ превод от Септуагинта и разликите между тях, освен в правописа, са само на отделни места и се изразяват в единични граматични или лексикални промени. Същевременно между двата бревиара има общи лексеми, по които те се различават от кирилските текстове. Освен това, там, където гръцкият текст е по-дълъг от латинския, хърватските бревиари или съвпадат с гръцкия, или в тях има следи от стария по-обширен текст, който съответсва на гръцкия. Чешкият глаголически текст съответства на латинския, като същевременно съдържа характерна чешка лексика, напр. opatrnost, kazn, zprava, počatek, blazen. Преводите ще бъдат коментирани по-подробно, като вариантите са разпределени в две групи - варианти, които се дължат на разликата между гръцкия и латинския текст, и варианти, които отразяват разлики в лексиката на славянските езици.

\section{1. Варианти, които се дължат на разликата между гръцкия и латинския текст}

\subsection{1. Разлики на синтактично равнище}

В 1,1 има разлика в определението към името на Соломон - в гръцки има подчинено изречение, въведено с относително местоимение (ò $\varsigma$

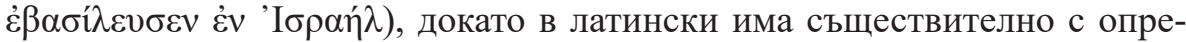

с латиница, са предадени по различен начин. Текстьт на Първия връбнички бревиар е поместен в транслитерация с кирилица, както е в изданието на Вайс. 
деление към него (regis Israhel). В двата бревиара и в чешкия текст намираме съчетание от съществително и прилагателно, както е в латински - c(êsa)ra iz(drai)l(e)va и krale izrahel'skeho. Но в хърватски е използвано съществителното се̂sarь, характерно за Кирило-Методиевите преводи, а в чешки - kral. Има разлика и в наставките на прилагателните, като в хърватски е използвано архаичното прилагателно iz(d)railevъ, което е за индивидуално притежание, докато чешкото izrahelskeho е за колективно притежание. В прилагателното iz(d)railevъ е отразена представата за Израил, като личност (това е името, което получава Яков след борбата с ангела), докато в чешкото прилагателно вече Израел се възприема като народ или страна. Първото прилагателно също е характерно за Кирило-Методиевите преводи, които са верни на библейската история. Трите кирилски текста се придържат към Септуагинта (ижє ц'ссдрьствова въ гслаили), като разликата между тях е само в относителното местоимение.

В 1,2 и 1,3 между латинския и гръцкия текст има еднотипни синтактични разлики: предложни конструкции с причастия (ad sciendam и ad intellegenda) срещу инфинитиви ( $\gamma v \tilde{\omega} v \alpha \iota$ и $\delta \varepsilon \dot{\xi} \alpha \sigma \theta \alpha i)$. В първия случай в двата хърватски бревиара, както и в чешки, намираме предложни конструкции с отглаголни съществителни: na poznanie в хърватски, а в чешки - k umieni. В кирилските текстове има инфинитив - познати (с вариант

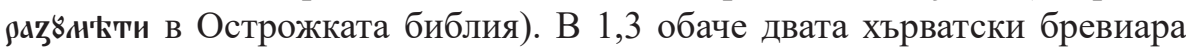
се различават: във Втория берамски има предложен израз с отглаголно съществително като в латински (na urazumênie), а в Първия връбнички -

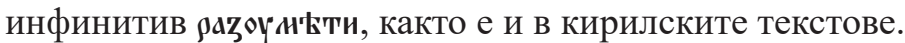

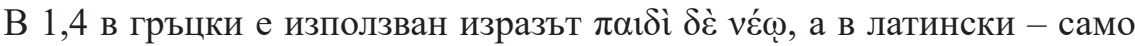
съществително: adulescenti. Двата хърватски бревиара съответстват на латинския текст с едно и също умалително съществително: ûnošicamь, юношицан, а в кирилските текстове има точно съответствие на гръцкия израз: штрокоу жє юноу. Съответствието в чешки е подобно на хърватскоTo: jinochu.

В 1,7 между гръцкия и латинския текст има разлика в словореда: А^џخे бофías фóßos Kvpíov и Timor Domini principium scientiae. Латинският словоред е възпроизведен във Втория берамски бревиар и в чешкия текст: strah' že g(ospoda)пь začelo premudrosti и bazen bžie počatek' mudrosti. В Първия връбнички бревиар словоредът е като в гръцки: Почєтк' пр'ЕноүАрости страх'

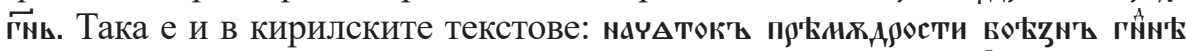

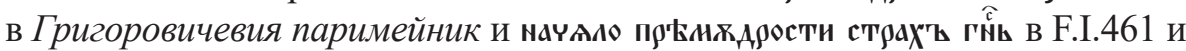
в Острожката билия. И в двата бревиара има лексикална успоредица с 
кирилските текстове: използвана е Кирило-Методиевата лексема premudrostb, докато в чешкия текст стои само mudrost.

В 1,9 също има разлика в словореда, като в гръцки изречението започва с наградата за мъдрия, а в латински - с предложна конструкция с гла-

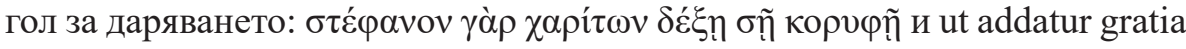
capiti tuo, като и наградата в двата текста е различна. В грьцки тя е бла-

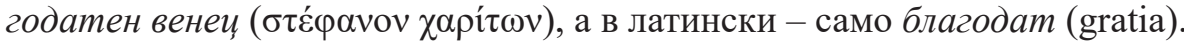
И тук двата хърватски бревиара се придържат към латинския словоред: da predast' se vênacь bl(a)godêt'ni gl(a)vê tvoei; Ad прндаст ск в'внць вагоA'Етни глав' твоєи. От разночетенията, които привежда Вайс, се вижда, че същият израз е използван и в останалите хърватски бревиари (VAJS 1910: 51). В Чешката глаголическа библия словоредът е същият, но текстьт е доста различен: at' bude dana sTva hlavie tvě. В кирилските текстове намираме точно съответствие На ГръцКИя: вънєцт Бо Бй

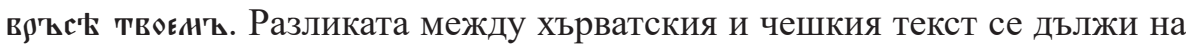
това, че в хърватския за названието на наградата се пази старият превод от гръцки: vênacь bl(a)godêt'ni, докато в чешки gratia е преведена съc slava. И във втората част на стиха хърватският превод пази старата основа

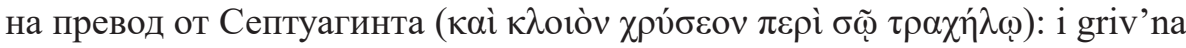
zlata šii tvoei; и гривна zлата шии твоєи, като съответства и на кирилските текстове (и гривнж злыт ж на своєи въії), докато в латински не се споменава злато (et torques collo tuo) и такова е съответствието в чешки: a nahr'dlek' šiji tvěi. Освен това думата grivna, употребена в хърватски, е същата като в кирилските текстове и съответства на гръцката кגolós.

\subsection{2. Разлики на лексикално равнище}

Някои от тях бяха вече посочени. Освен това има още някои. В 1,4 в гръцки стои а̇ка́коเৎ ('на незлобивите, невинните'), а в латински - parvulis ('на децата, юношите'). В двата хърватски бревиара преводът съответства на латинския текст, но с различни лексеми: ml(a)dên'cemь във Втори берамски и д'ЕТен' в Първи връбнички. В чешки също има съответствие на латинския: robatom' а в кирилските текстове - на гръцкия:

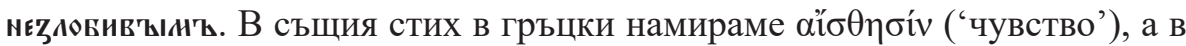
латински - scientia ('знание'). Хърватските бревиари и чешкият превод следват латински, но отново с различни съответствия в двата бревиара: umênie и в‡д съответстват на гръцкия с чюв'ъствиє. 


\subsection{3. Различни изрази с подобно значение}

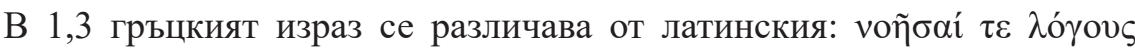

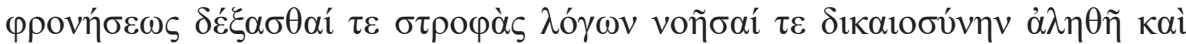

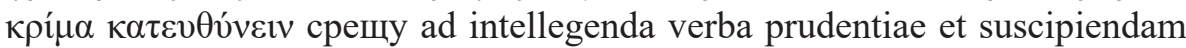
eruditionem doctrinae iustitiam et iudicium et aequitatem. В гръцки има из-

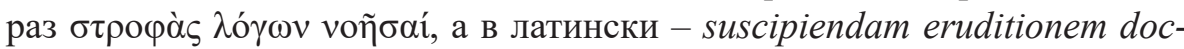

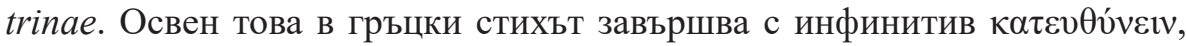
който се отнася до крі́ $\alpha$ : да се поправя съдът, т.е. да се прави справедлив. В латински има съществително - aequitatem, което не пояснява предходното iudicium, а е добавено със съчинителния съюз еt. В кирилските източници има точно (дори буквално) съответствие на израза в Септуа-

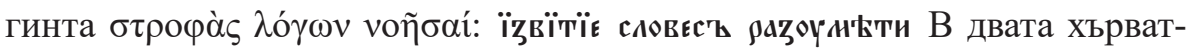
ски бревиара има изрази, между които има известни разлики, но и двата съответстват на латинския: na priêtie učeniê nauka във Втори берамски и При'Тти строєниє оүчєни' В Първи връбнички. От вариантите, които Привежда Вайс, се вижда, че Видовият и Пашманският бревиар сьвпадат с Първия връбнички, а Ватиканският и Първи и Втори новлянски - с Втория берамски. Краят на стиха във Втория берамски бревиар съответства точно на латинския: pr(a)vdi i suda. i pravosti (така е и във Ватиканския), докато в Първи връбнички е само правди и соүда (така е във Видовия), т.е. липсва съответствието на et aequitatem, но също и съответствието на

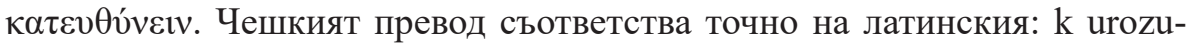
mieni slov' opatrnosti a k przijeti umielěho naučenie. spravedlivosti i suda. i pravosti.

\subsection{4. Разлики в дължината на текста}

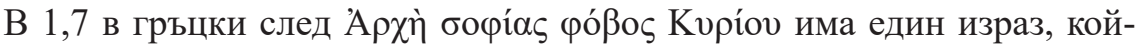

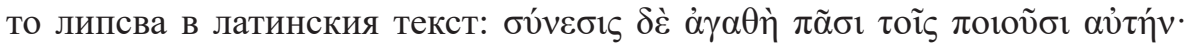

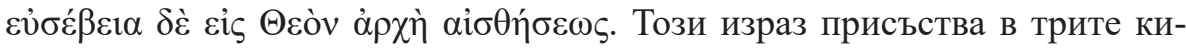
рилски текста, като между тях има някои разлики, които се дължат на

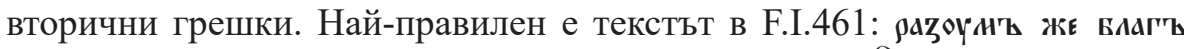

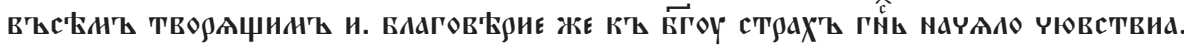

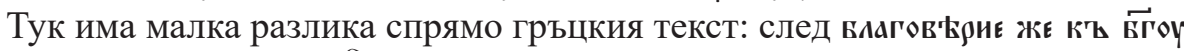

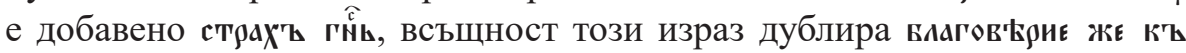

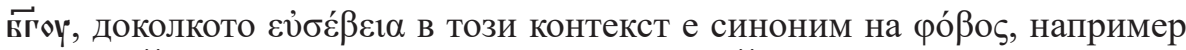

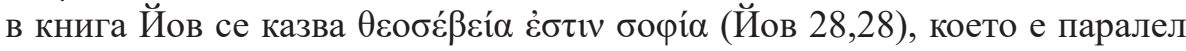

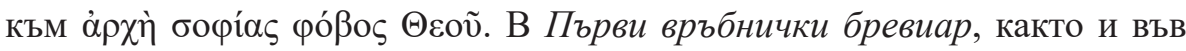




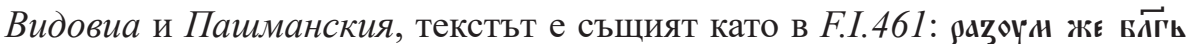

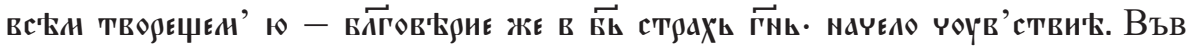
Втория Берамски бревиар не е включено цялото изречение, но има остатьци от него: strahь g(ospoda)nь načelo čuv's'tviû. Тази фраза е изведена на първо място в стиха, пред strah’ že g(ospoda)nь začelo premudrosti. Това разместване е резултат от преработката на текста, при която е била съкратена една част, която липсва в латински, но все пак е останала част от израза, който съответства на гръцкия текст, и тя е била преместена в началото на стиха.

\section{2. Лексикални разлики в славянските преводи при съответствията на думи, които в гръцки и в латински имат приблизително еднакво значение}

В тези случаи двата хърватски текста съвпадат най-често с кирилските. Съвпадението с кирилските текстове е при съответствието на $\pi \alpha \rho \mu_{\mu} \alpha$ - parabola: pritča - притъца срещу poviestь в чешки; на бофí $\alpha$ - sapientia:

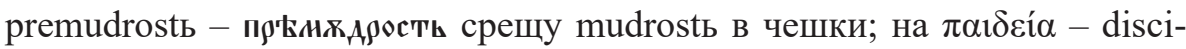
plina: nakazanie - наказанию срещу kazn в чешки; на фро́vๆбıৎ - prudentia:

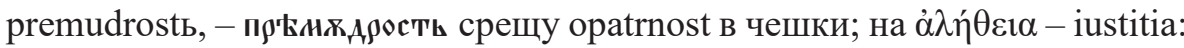
pravbda - правьда срещу spravedlivost; на $\alpha i v i ́ \gamma \mu \alpha \tau \alpha$ - enigmata: gananiê -

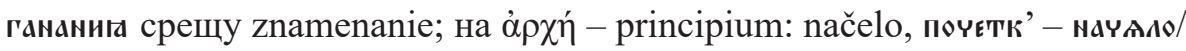
начАток'ъ срещу počatek. Ще обърна внимание на думата gananie, която означава 'загадка'. Тя е много рядка, но е употребена и в най-ранния превод на Псалтира (Пс 48,5) със същото значение като съответствие на

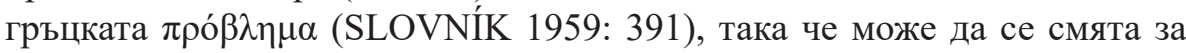
Кирило-Методиевска.

Случаите, в които в двата бревиара има едно и също или близки съответствия и хърватската лексема се различава от лексемата в кирилските източници са три, като в два от тях хърватският и чешкият превод съвпадат: при превода на ह̌vvoı - intellectus c razumь в двата хърватски и rozum в чешки срещу съмыск' в кирилските източници; при превода

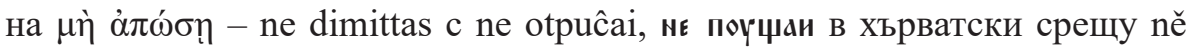
ostavai в чешки и три различни съответствия в кирилските източници:

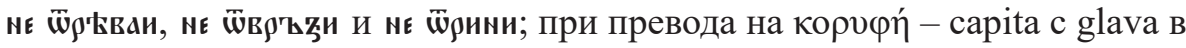
двата хърватски и hlava в чешки срещу вюххъ в кирилските източници. Разликата между славянските преводи в последния случай се дължи на многозначността на гръцката дума, която може да означава и 'връх на 
главата' ('теме'), и 'връх, връхна точка'. Тук хърватският текст е поправен според латинския.

На две места в двата хърватски бревиара има различни съответствия. Първото е в 1,4. Гръцката $\pi \alpha v o v \rho \gamma i ́ \alpha$ и латинската astutia имат близки значения, и двете означават 'хитрост, ловкост, сръчност', като гръцката дума може да има и негативно значение - 'коварство, измама'. Съответствието във Втория берамски бревиар (и във Ватиканския и Първи и Втори новлянски) е nauka, в чешки - 'opatrnost', а в Първи връбнички бревиар (и във Видовия и Пашманския), както и в Григоровичевия паримейник - ко-

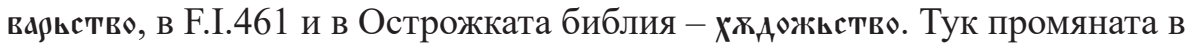
хърватски е въведена не с цел сближаване с латинския текст, а за да се намери по-подходящо съответствие според контекста. По сыщата причина мястото е редактирано и в кирилската традиция като думата көвырьство, която е развила негативно значение, е заменена с хқдяжкство. Второто

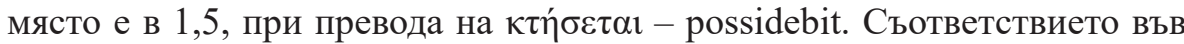
Втори берамски бревиар е obladaetь, в Първи връбнички е стєжит', както и в кирилските - стьтажит'ы, а чешкото e vlasti bude.

Лексикалните разлики между славянските текстове са представени в таблица. Тъй като трите кирилски текста най-често съвпадат, са дадени в една колона, а когато между тях има различия, вариантите са поставени един под друг.

Таблица 1. Лексикалните разлики между славянските текстове Table 1. Lexical differences between Slavonic texts

\begin{tabular}{|c|c|c|c|c|c|c|}
\hline стих & гръцки & латински & $\begin{array}{c}\text { Втори берам- } \\
\text { ски бревиар }\end{array}$ & $\begin{array}{c}\text { Първи } \\
\text { връбнички } \\
\text { бревиар }\end{array}$ & $\begin{array}{c}\text { Чешка } \\
\text { глаголическа } \\
\text { библия }\end{array}$ & $\begin{array}{c}\text { Григ. парим., } \\
\text { F.I.461, } \\
\text { Остр. библ. }\end{array}$ \\
\hline 1,1 & $\pi \alpha \rho o \mu^{\prime} \alpha$ & parabola & pritıča & приттуа & poviest & приттъча \\
\hline 1,2 & бофía & sapientia & premudrostb & пртноудрость & mudrost & прТндАрость \\
\hline 1,2 & 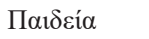 & disciplina & nakazanie & каZание & kaznь & накаZанињ \\
\hline 1,2 & $\varphi \rho o ́ v \eta \sigma ı s$ & odetacul & premudrostb & пртноүА९ость & opatrnost & 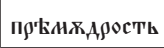 \\
\hline 1,3 & $\dot{\alpha} \lambda \eta \dot{\theta} \theta \varepsilon \iota \alpha$ & iustitia & pravbda & Правьда & spravedlivost & Правьда \\
\hline 1,4 & 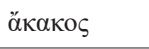 & parvulis & mladênacь & A'ETEE & robatb & НЕZАОБИВ' \\
\hline 1,4 & $\pi \alpha v o v \rho \gamma i ́ \alpha$ & astutia & naukb & кова丿'сттво & opatrnost & $\begin{array}{l}\text { ковајьство } \\
\text { ХХАожьство }\end{array}$ \\
\hline 1,4 & 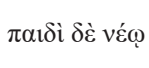 & adulescenti & ûnošicamb & юношицая & jinochu & $\begin{array}{l}\text { штрокоу же } \\
\text { юноу }\end{array}$ \\
\hline
\end{tabular}




\begin{tabular}{|c|c|c|c|c|c|c|}
\hline 1,4 & $\alpha i ̋ \theta \eta \eta \sigma ı s$ & scientia & umênie & в安д安ниє & umienie & ЧюВЪСТТВИЕ \\
\hline 1,4 & Ěvvoid & intellectus & razumb & gazoyн & rozum & с'қдысысл'қ \\
\hline 1,5 & $\kappa \nu \beta \varepsilon ́ \rho v \eta \sigma ı \varsigma$ & gubernacula & stroenie & строєние & zprava & стГОИТТЕАСТТВО \\
\hline 1,5 & $\kappa \tau \eta ́ \sigma \varepsilon \tau \alpha \iota$ & possidebit & obladaetь & стежит' & vlasti bude & стАжить \\
\hline 1,6 & $\alpha i v i ́ \gamma \mu \alpha \tau \alpha$ & enigmata & gananiê & Ганани & znamenanie & гананита \\
\hline 1,7 & $\dot{\alpha} \rho \chi \eta ́$ & principium & načelo & ПОчетК' & počatek & $\begin{array}{l}\text { НАYАTОК' } \\
\text { НАYAADO }\end{array}$ \\
\hline 1,7 & Фóßos & timor & strahb & страхх' & bazen & 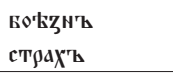 \\
\hline 1,7 & $\dot{\alpha} \sigma \varepsilon \beta \varepsilon \bar{i} \varsigma$ & stulti & повреден & БеZоYАнИ & blaznově & нЕчьстивии \\
\hline 1,7 & $\begin{array}{l}\dot{\varepsilon} \xi o v \theta \varepsilon v \eta ́ \sigma o v- \\
\sigma \mathrm{\iota v}\end{array}$ & despiciunt & повреден & оүничижают' & hr'daji & $\begin{array}{l}\text { оуничижить } \\
\text { похоулАтть }\end{array}$ \\
\hline 1,8 & 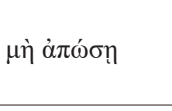 & ne dimittas & ne otpuĉai & нЕ поүџаи & ně ostavai & 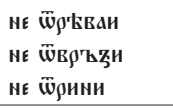 \\
\hline 1,9 & 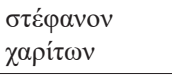 & gratia & $\begin{array}{l}\text { vênacь } \\
\text { bl(a)godet'ni }\end{array}$ & $\begin{array}{l}\text { в'Енць } \\
\text { вАГода'Ттни }\end{array}$ & stva & 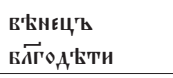 \\
\hline 1,9 & $\kappa о \rho v \varphi \tilde{n}$ & capiti & gl(a)vê & ГлАв' & hlavie & 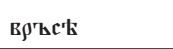 \\
\hline 1,9 & 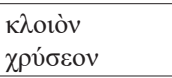 & torques & grivbna zlata & гривна zлатта & nahr'dlek' & гривьна zаdта \\
\hline
\end{tabular}

\section{3. ПРИТЧИ СОЛОМОНОВИ 3,13-20}

И при това четиво между гръцкия и латинския текст има разлики на структурно и на лексикално равнище, а също и в дължината на текста. Този път обаче разликите между двата бревиара са много повече и по-значителни, като във всички случаи се дължат на промени спрямо първоначалния превод във Втория берамски, докато Първият връбнич$\kappa и$ се придържа изцяло към превода от гръцки и съвпада с кирилските текстове. Хървоевият мисал, в който по-голямата част от текста съответства на латинския, е близо до Втория берамски бревиар. На някои места обаче в него личи стар превод от гръцки и тогава той сьвпада лексикално с Първия връбнички и кирилските текстове. Трите кирилски текста отново съвпадат в голяма степен, а Чешката глаголическа библия съдържа превод от латински, в който са употребени характерни чешки лексеми: užitek, pravica, cesta, pokoine, propast. По-надолу разликите между славянските текстове са коментирани по-подробно. 


\section{1. Разлики между гръцкия и латинския текст}

\subsection{1. Различни изрази с подобно значение}

На две места в гръцкия и в латинския текст има изрази, които се различават съществено помежду си, но носят едно и също послание. Пьрвото място

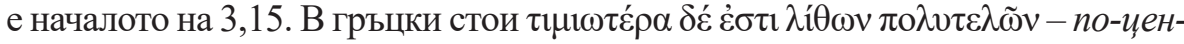
на е от скъпоценни камъни, а в латински: Fructus eius pretiosior est cunctis opibus - нейният плод е по-иенен от всички дела. Тук двата хърватски бревиара се различават. Във Втори берамски, както и в Хървоевия мисал, текстьт съответства на латинския: plodь ee mnogocên'ni e(stь) vsêhь dêlь, докато в Първи връбнички преводът е според грьцкия текст: Араж'ши жє єст' камєни'太 нногоц'Енна и съвпада с кирилските, както и с Видовия бревиар. В чешки има превод от латински, като съответствието на fructus e užitek: Užitekь ejie dražši est nade vše zbožie. Тук обаче има една интересна особеност във Втори берамски бревиар и Хървоевия мисал, която свидетелства за връзка с ранния превод, запазен в Първия връбнички бревиар и в кирилските текстове: съответствието на pretiosior ( пен, както е и в Първия връбнички бревиар, и в кирилските текстове, и в чешки (при това едно и също: дражши, dražši), a e mnogocênni, което се открива във

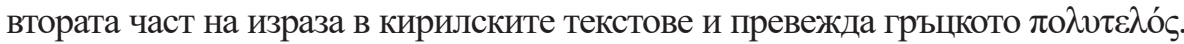
Това показва, че изразьт в хьрватските текстове е преправен от израз, който е бил част от най-ранния превод и е съответствал на грьцкия текст.

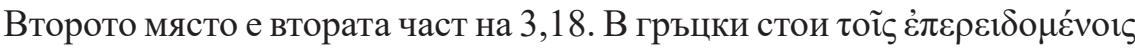

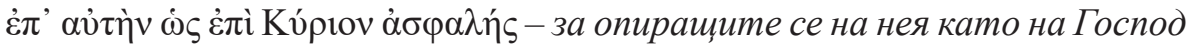
е сигурна (непоколебима), а в латински - qui tenuerit eam beatus - който я запазва, е блажен. В Първи връбнички бревиар изразът съответства на

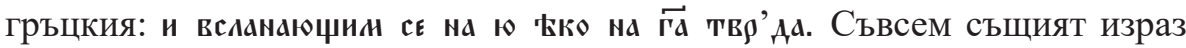
стои и в кирилските текстове, както и във Видовия бревиар, само че в него вместо на га погрешно е написано нога (VAJS 1910: 59). Във Втори берамски бревиар изразът е променен в съответствие с латинския: b(la)ž(e)nь iže držit' û, в Хървоевия мисал той е пропуснат, но в се намира в Рочкия мисал и също съответства на латинския: i iže dr’žetь ju. В Чешката глаголическа библия този израз липсва.

\subsection{2. Разлики на синтактично равнище}

В 3,14 в грьцки има инфинитив: $\dot{\varepsilon} \mu \pi о \rho \varepsilon v ́ \varepsilon \sigma \theta \alpha 1$, а в латински - отглаголно съществително: adquisitio. Във Втори берамски бревиар, в Хърво- 
евия мисал и в Чешката глаголическа библия стоят отглаголни съществителни: priiskanie, preiskanie, nalezenie, а в Първи връбнички бревиар и в кирилските текстове - инфинитив: коүповати. В края на втората фраза в

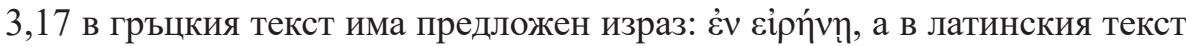
- прилагателно: pacificae. И тук Вторият берамски бревиар и Хървоевият мисал следват латинския с прилагателното mirni, а в Първи връбнички бревиар и кирилските текстове има превод от грьцки: с въ зият. В чешкия текст преводът е от латински: pokoine, B 3,18 има два паралелни израза, в които в грьцки са използвани сегашни деятелни причастия, а в латински - подчинени изречения, въведени с относителни местоимения:

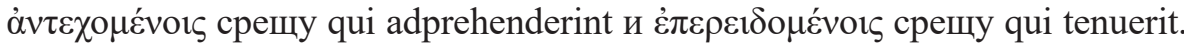
И в двата случая Първи връбнички бревиар и кирилските текстове съответстват на гръцкия със сегашни деятелни причастия: Ая'жєцин ск и вслdнаючин ск. Вторият берамски бревиар и Хървоевият мисал обаче имат различни изрази на двете места. В първия случай в двата хърватски текста има причастия: dr'žeĉim и pridržećimь se, а във втория случай - подчинени изречения, въведени с iže, които съответстват на латинския текст: iže držit' и iže dr’žetь. В чешкия текст първият израз съответства на латинския с подчинено изречение, въведено c ktož, а вторият израз липсва.

В 3,20 между гръцкия и латинския текст има разлика в словореда:

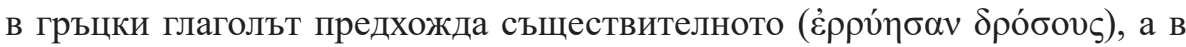
латински съществителното предшества глагола (rore concrescunt). При славянските преводи двата хърватски текста (във Втория берамски бревиар и в Хървоевия мисал, в Първия връбнички този стих липсва) и трите кирилски следват словореда на грьцкия текст, като бревиарьт съвпада с кирилските текстове и лексикално: potočiše rosi; vzrastut rosoju; поточиш (точишА) росты. А чешкият текст възпроизвежда словореда на латинския: rosu se srostuji. Тук също в мисала може да се види връзка на хърватския текст с ранен превод, направен от грьцки, като старият словоред е запазен, а е направена лексикална промяна.

\subsection{3. Разлики на лексикално равнищее}

На няколко места има лексикални разлики между гръцки и латински. В 3,13 в грьцки стои $\varepsilon \tilde{i} \delta \varepsilon-$ видя, а в латински глагольт e affluit - изобилства. Глагольт във Втория берамски бревиар, Хървоевия мисал и Чешката глаголическа библия съответства на латинския: obiluetь, przipliva, а в Първи връбнички бревиар и в кирилските ръкописи съответства на 


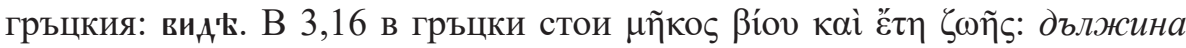
на живота и на годините за живеене, а в латински - longitudo dierum - дължина на дните. И тук Вторият берамски бревиар, Хървоевият мисал и Чешката глаголическа библия съответстват на латинския с dni, dnov', а Първи връбнички бревиар и кирилските - на гръцкия с жити' и л'大тd живота. В 3,18 грьцкият и латинският текст се различават не само синтактично, а и лексикално. Както беше посочено, в гръцки има две причастия, а в латински две подчинени изречения. Пьрвото гръцко при-

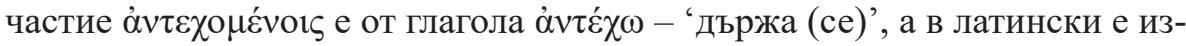
ползван глагольт adprehenderint от adprehendo, който има първо значение 'хващам', но може да означава и 'задържам'. И трите хърватски съответствия: dr'žeĉim', Ая'жєщин ск и pridržećimь se, съответстват на гръцкиото и съвпадат с кирилското дљ'ъжжчият с popadne. Първата част от стиха е посочена и от Райнхарт като пример за място, на което текстът в мисала съответства на гръцкия, а не на латин-

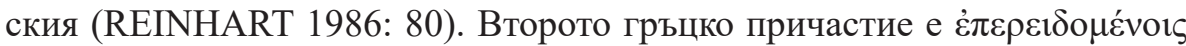

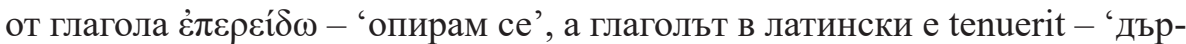
жи, подпира'. Този път двата хърватски бревиара се различават помежду си. Вторият берамски, както и Хървоевият мисал, съответстват на латинския, както синтактично, така и лексикално: iže držit' и iže dr’žetь, а в чешки тази фраза липсва. Първи връбнички бревиар и кирилските текстове съответстват на гръцкия синтактично и лексикално: всланающия $\mathfrak{c}$, като правилно е избран този нюанс в значението, който най-много подхожда на контекста: 'осланям се'.

\subsection{4. Разлики в дължината на текстовете}

И в това четиво в гръцки има изрази без съответствие в латинския

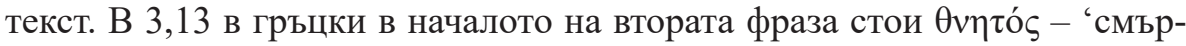
тен'. Така се осьществява изразяването на мисълта чрез две паралелни конструкции от синонимни изрази: блажен е човекът, който е намерил мъдрост и смъртният, който притежава разум. По този начин се получава пълно успоредяване със синоними: подлозите са човек и смъртен, типична синонимна двойка за библейските текстове, глаголите са намирам и притежавам, които назовават два етапа от един процес, но се използват като синоними, а допълненията са мъдрост и разум. В латинския текст липсва подлогът на втората фраза и по този начин се нарушава успоредяването на двата израза. Изразяването чрез паралелни конструкции 
е типичен похват на еврейската словесност и гръцкият текст съответства в по-голяма степен на еврейския начин на говорене. Вторият берамски бревиар, Хървоевият мисал и чешкият текст съответстват на латинския - без подлог на второто изречение, Първият връбнички бревиар и два от кирилиските отговарят на гръцкия, със съответствие стылытын' на $\theta v \eta \tau o ́ s$, а в третия (Острожката библия) липсва втората част от стиха.

По-нататьк, както беше посочено, началото на 3,15 е различно в гръцки и в латински, а след началната фраза в гръцкия текст има един

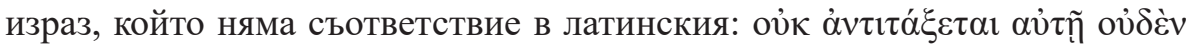

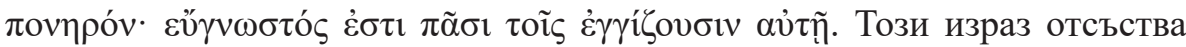
във Втория берамски бревиар, Хървоевия мисал и Чешката библия, а се намира в Първия връбнички бревиар и в кирилските източници: нє пюоти-

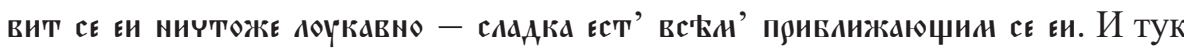
Бревиарът на Вид Омиилянин съвпада с Първия връбнички, а Първи и Втори новлянски и Ватиканският с Втория берамски.

В края на 3,16 в гръцки има един доста дълъг израз, който отсъст-

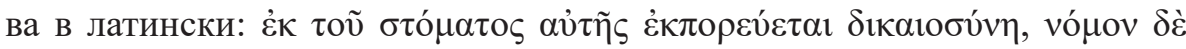

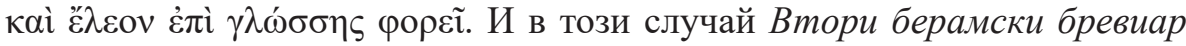
и чешкият текст съответстват по дължина на латинския, но в Хървоевия мисал в края на стиха има допълнение, което липсва в латинския, а не съответства и на гръцкия текст: Blaga e(stь) vsěmь blizь ee budučimь. i vsako drago něstь takmeno ei. В Първия връбнички бревиар и в кирилските текстове има съответствие на допълнителния гръцки израз: 今̊ оустьн' єє

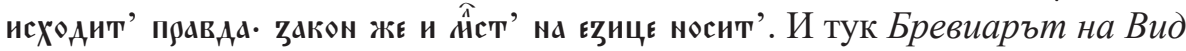
Омиилянин съвпада с Първия връбнички, а Първи и Втори новлянски и Ватиканският с Втория берамски. Този цитат от Притчи 3,16 е доста популярен в старобългарската литература. Ще го открием например в Похвално слово за св. Кирил Философ от Климент Охридски: Ћкоже ९єчє

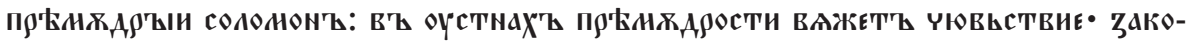

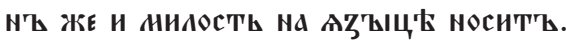

\section{2. Лексикални разлики в славянските преводи при съответствията на думи, които в гръцки и в латински имат приблизително еднакво значение}

При тези лексикални варианти по-често хърватските текстове съвпадат помежду си и с кирилските, но понякога се различават. Случаите, 
когато трите хърватски текста съвпадат помежду си и с кирилските тек-

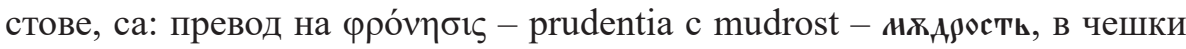

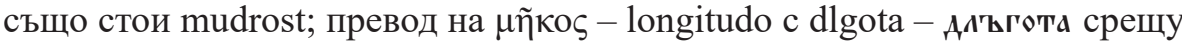
prodlenie в чешки; превод на $\delta \varepsilon \xi ı \alpha ́ \alpha$ - dextera c desnica - Аєсница срещу

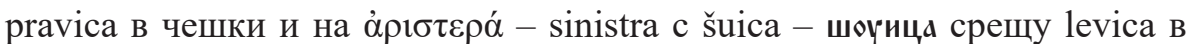
чешки; превод на $\pi \lambda$ об̃ $\varsigma_{-}$- divitia c bogatastvo - вогатьствю, а в чешкия текст стои съществително от същата основа, но с друга наставка: bohat-

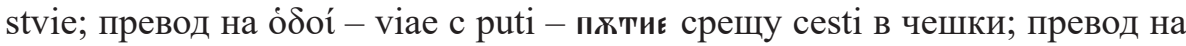
$\dot{\varepsilon} \theta \varepsilon \mu \varepsilon \lambda i ́ \omega \sigma \varepsilon$ - fundavit с osnova - основ срещу založil est в чешки.

Случаите, в които двата хърватски бревиара съвпадат лексикално с кирилските текстове, а се различават от Хървоевия мисал, са следните: превод на относителното местоимение с iže - ижє срещу ki в Хървоевия мисал и enž в чешките текстове (на други места обаче и в Хървоевия мисал се използва iže); превод на $\varepsilon \tilde{j} \rho \varepsilon$ - invenit с obrêĉetь (в сегашно време

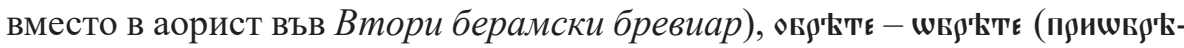
тє) срещу naidetь в Хървоевия мисал и nalezl в чешки; превод на крєібббоv - melior c lučše - лючє срещу bolše в Хървоевия мисал и lepšie в чешки;

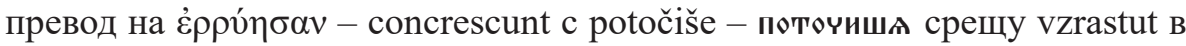
Хървоевия мисал и se srostuji в чешки.

На едно място двата хърватски бревиара се различават, като Вторият берамски съвпада с Хървоевия мисал и с Чешката глаголическа библия, а Първият връбнички съвпада с кирилските текстове: в 3,17 при превода на калаí - pulchrae с krasni във Втория берамски бревиар и Хървоевия мисал и krasne в чешки срещу докөи в Първия връбнички бревиар и в кирилските текстове.

Има един случай, в който Първи връбнички бревиар и Хървоевият мисал пазят стария превод и съвпадат с кирилските текстове, а във Bтори берамски бревиар има промяна. Той е при превода на определението към

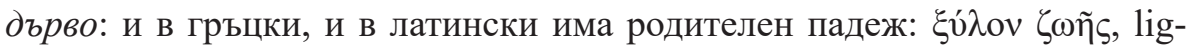
num vitae. В Първи връбнички бревиар, в Хървоевия мисал и в кирилските текстове преводът е с Альво животно срещу drêvo (živo)ta във Втори берамски и drzevo viečneho života в чешки. Освен това в двата стиха, които липсват в Първи връбнички бревиар $(3,19-20)$ има още няколко случая, при които Хървоевият мисал съвпада с кирилските текстове, а се различава от Втория берамски бревиар: превод на бофі́ - sapientia c premudrostь - пржндарости срещу mudrostь във Втори берамски бревиар и smisl в Чешката глаголическа библия; превод на а̋ßvббо - abyssi c bezdni вєъдън'ы срещу propasti в чешки, а във Втори берамски бревиар този 


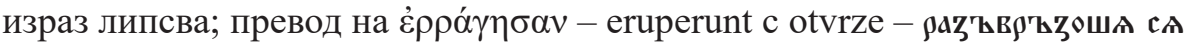
(с различни представки) срещу prorazi във Втори берамски бревиар и virzinuli jsu в чешки.

В последните два стиха има два случая, когато хърватските текстове съвпадат помежду си и се различават и от чешкия, и от кирилските: в

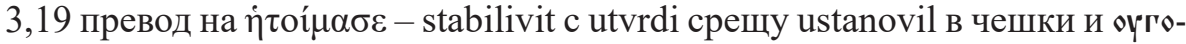
това в кирилските източници; пак в 3,19 превод на фроvи́бє1-prudentia c razumomь срещу mudrosti в чешки и нждростиж в кирилските източници.

В таблицата са представени основните лексикални разлики между славянските текстове, като са включени както случаите на разлики между гръцкия и латинския текст, така и случаите, в които те съдържат лексеми с еднакво или близко значение.

Таблица 2. Основните лексикални разлики между славянските текстове на Притчи Соломонови 3,13-20

Table 2. The main lexical differences between Slavonic texts of the Book of Proverbs 3,13-20

\begin{tabular}{|c|c|c|c|c|c|c|c|}
\hline стих & гръцки & латински & $\begin{array}{c}\text { Втори } \\
\text { берамски } \\
\text { бревиар }\end{array}$ & $\begin{array}{c}\text { Първи } \\
\text { връбнички } \\
\text { бревиар }\end{array}$ & $\begin{array}{c}\text { Хървоев } \\
\text { мисал }\end{array}$ & $\begin{array}{c}\text { Чешка } \\
\text { глагол. } \\
\text { библия }\end{array}$ & $\begin{array}{c}\text { Григ. } \\
\text { паримейник } \\
\text { F.I.461 } \\
\text { Острожка } \\
\text { библия }\end{array}$ \\
\hline 3,13 & ö $\zeta$ & qui & iže & ижє & ki & enž & ижє \\
\hline 3,13 & 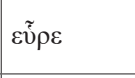 & invenit & obrêĉetь & 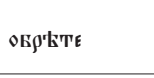 & naidetb & nalezl' & 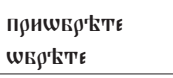 \\
\hline 3,13 & бофíav & sapientiam & mudrosti & 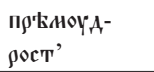 & mudrostb & smisl' & 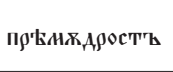 \\
\hline 3,13 & $\varepsilon \tilde{i} \delta \varepsilon$ & affluit & obiluetь & вид & obiluet' & przipliva & виде \\
\hline 3,13 & 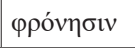 & prudentia & mudrostiû & НоУАЯостт' & mudrostiju & mudrost' & 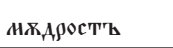 \\
\hline 3,14 & $\kappa \rho \varepsilon \tilde{\imath} \sigma \sigma o \nu$ & melior & lučše & AOYYE & bolše & lepšie & ALYE \\
\hline 3,14 & $\begin{array}{l}\dot{\varepsilon} \mu \pi \mathrm{o} \rho \varepsilon \varepsilon^{-}- \\
\sigma \theta \alpha \iota\end{array}$ & adquisitio & priiskanie & коүповати & preiskanie & nalezenie & коуповати \\
\hline 3,15 & 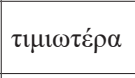 & pretiosior & $\begin{array}{l}\text { mnogo- } \\
\text { cênni }\end{array}$ & А९аж'ши & $\begin{array}{l}\text { mnogo- } \\
\text { cěnanь }\end{array}$ & dražši & дяаж'ъшї \\
\hline 3,16 & $\mu \tilde{\eta} \kappa о \varsigma$ & rudentia & dlgota & AльгоTA & dl'gota & prodlenie & AА'ҚготА \\
\hline 3,16 & 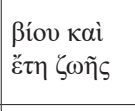 & dierum & dni & $\begin{array}{l}\text { житит } \\
\text { и иtта } \\
\text { живота } \\
\end{array}$ & dni & dnov' & $\begin{array}{l}\text { житит и Аtтта } \\
\text { живота }\end{array}$ \\
\hline 3,16 & $\delta \varepsilon \xi_{l} \alpha \dot{ }$ & dextera & dêsnica & АЕсеница & desnica & pravica & АєЕсница \\
\hline 3,16 & $\grave{\alpha} \rho t \sigma \tau \varepsilon \rho \alpha$ & sinistra & šuica & шоүица & šuica & levica & шоүица \\
\hline
\end{tabular}




\begin{tabular}{|c|c|c|c|c|c|c|c|}
\hline 3,16 & $\pi \lambda \mathrm{oṽ} \tau \mathrm{s}$ & divitia & bogatastvo & БГат'сттво & bogatastvo & bohatstvie & Богат"Қетво \\
\hline 3,17 & ódoí & viae & puti & поути & puti & cesti & ПХТТЕ \\
\hline 3,17 & $\kappa \alpha \lambda \alpha i$ & pulchrae & krasni & АОБ & krasni & krasne & АоБ \\
\hline 3,17 & $\tau \rho i ́ \beta o \imath$ & semitae & stazi & стьzи & stazi & stezi & стLgA \\
\hline 3,17 & 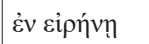 & pacificae & mirni & в нирт & mir'ni & pokoine & в'ъ нияе \\
\hline 3,18 & $\xi \hat{\lambda} \lambda \mathrm{ov} \zeta \omega \tilde{\eta} \varsigma$ & $\begin{array}{l}\text { lignum } \\
\text { vitae }\end{array}$ & $\begin{array}{l}\text { drêvo } \\
\text { (živo)ta }\end{array}$ & $\begin{array}{l}\text { А९tво } \\
\text { животно }\end{array}$ & $\begin{array}{l}\text { drěvo } \\
\text { život'no }\end{array}$ & $\begin{array}{l}\text { drzevo } \\
\text { viečneho } \\
\text { života }\end{array}$ & А९६Ево животно \\
\hline 3,18 & $\begin{array}{l}\dot{\alpha} \nu \tau \varepsilon \chi 0 \mu \varepsilon^{-} \\
\nu 01 \zeta\end{array}$ & $\begin{array}{l}\text { qui adpre- } \\
\text { henderint }\end{array}$ & dr'žeĉim' & А $\rho^{\prime}$ ЖЕчин $\mathfrak{c}$ & $\begin{array}{l}\text { pridržećimb } \\
\text { se }\end{array}$ & $\begin{array}{l}\text { ktož'ji } \\
\text { popadne }\end{array}$ & $\begin{array}{l}\text { А९'ъжжциия'ъ } \\
\mathrm{c} \Delta\end{array}$ \\
\hline 3,18 & 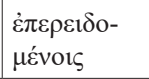 & qui tenuerit & iže držit' & $\begin{array}{l}\text { ВСААНАюЧИН } \\
\text { СЕ }\end{array}$ & iže dr'žetı & & 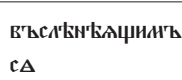 \\
\hline 3,19 & бофía & sapientia & mudrost & липсва & premudrost & smisl & 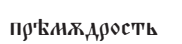 \\
\hline 3,19 & $\begin{array}{l}\dot{\varepsilon} \theta \varepsilon \mu \varepsilon \lambda i ́ \omega- \\
\sigma \varepsilon\end{array}$ & fundavit & osnova & липсва & osnova & $\begin{array}{l}\text { založil' } \\
\text { est }\end{array}$ & шснова \\
\hline 3,19 & $\dot{\eta} \tau o \dot{\mu} \mu \alpha \sigma \varepsilon$ & stabilivit & utvr'di & липсва & utvrdi & ustanovil & оүготова \\
\hline 3,19 & $\varphi \rho о v \eta ́ \sigma \varepsilon ı$ & prudentia & razumomь & липсва & razumoms & mudrosti & нкАлюсттиА \\
\hline 3,20 & $\begin{array}{l}\dot{\varepsilon} v \\
\alpha i \sigma \theta \eta ́ \sigma \varepsilon 1\end{array}$ & sapientia & mudrostb & липсва & mudrostb & mudrosti & 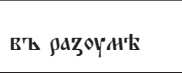 \\
\hline 3,20 & $\alpha \not \beta v \sigma \sigma o \imath$ & abyssi & $\begin{array}{l}\text { липсва } \\
\text { думата }\end{array}$ & липсва & bezdni & propasti & БЕЪАТ'ҚН'Ы \\
\hline 3,20 & 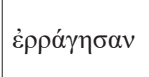 & eruperunt & prorazi & липсва & otvrze & $\begin{array}{l}\text { virzinuli } \\
\text { jsu }\end{array}$ & 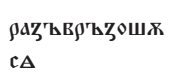 \\
\hline 3,20 & 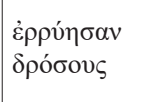 & $\begin{array}{l}\text { rore con- } \\
\text { crescunt }\end{array}$ & $\begin{array}{l}\text { potočiše } \\
\text { rosi }\end{array}$ & липсва & $\begin{array}{l}\text { vzrastut } \\
\text { rosoju }\end{array}$ & $\begin{array}{l}\text { rosu se } \\
\text { srostuji }\end{array}$ & 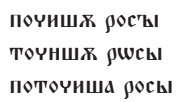 \\
\hline
\end{tabular}

\section{4. ЗАКЛЮЧЕНИЕ}

Можем да обобщим данните от сравнението на текста на двете четива от Притчи Соломонови в различни средновековни паметници по следния начин. Почти всички разлики между двата бревиара се дължат на това, че във Втория берамски текстът е променен, а в Първия връбнички се пази ранният превод. В първото четиво разликите между двата хърватски бревиара са малко и не са значителни, а във второто четиво тези разлики са много повече и по-съществени, като се отнасят преди всичко до синтактичните конструкции и до обема на текста. На лексикално равнище и Вторият берамски бревиар запазва близостта си до кирилските текстове. Във второто четиво текстьт във Втория берамски 
бревиар и в Хървоевия мисал съвпада до голяма степен и съответства на латинския текст. Също така и трите кирилски текста съвпадат почти напълно, разликите между тях са на равнище единични замени или грешки и очевидно възхождат към един и същ древен превод, който с голяма вероятност може да се смята за Кирило-Методиевски.

Отношението на двата бревиара към гръцкия и латинския текст, както и помежду им, е показано нагледно в две таблици. На едната са представени случаите, когато двата сьвпадат, а се различават от Септуагинта и от кирилските текстове. На другата са показани случаите, в които се различават помужду си, като единият следва латинския, а другият - гръцкия текст и превода, представен в кирилските текстове.

Таблица 3. Общи четения между двата бревиара, които съответстват на латинския текст

Table 3. Common lectures in the two Breviaries corresponding to Latin text

\begin{tabular}{|c|c|c|c|c|c|}
\hline стих & гръцки & латински & Втори берамски & $\begin{array}{c}\text { Първи } \\
\text { връбнички }\end{array}$ & $\begin{array}{c}\text { кирилски } \\
\text { текстове }\end{array}$ \\
\hline 1,1 & $\begin{array}{l}\text { òs } \dot{\varepsilon} \beta \alpha \sigma i ́ \lambda \varepsilon v \sigma \varepsilon v \\
\dot{\varepsilon} v ' I \sigma \rho \alpha \eta ́ \lambda\end{array}$ & regis Israhel & $\begin{array}{l}\text { c(êsa)ra } \\
\text { iz(drai)l(e)va }\end{array}$ & цра из̆ава & 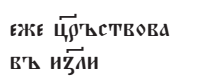 \\
\hline 1,2 & 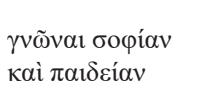 & $\begin{array}{l}\text { ad sciendam } \\
\text { sapientiam et } \\
\text { disciplinam }\end{array}$ & $\begin{array}{l}\text { na poznanie } \\
\text { premudr(o)sti i } \\
\text { nakazanie }\end{array}$ & 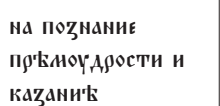 & 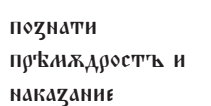 \\
\hline 1,3 & 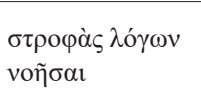 & $\begin{array}{l}\text { suscipiendam } \\
\text { eruditionem } \\
\text { doctrinae }\end{array}$ & $\begin{array}{l}\text { na priêtie učeniê } \\
\text { nauka }\end{array}$ & 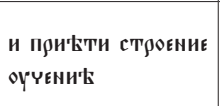 & 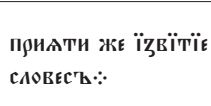 \\
\hline 1,4 & 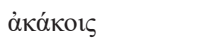 & parvulis & ml(a)dên'cemь & A'ЕTEA' & НЕ马АОБИВ'ЫАҢ' \\
\hline 1,4 & 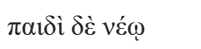 & adulescenti & ûnošicamь & юношицая & Шт९окоY Же юноу \\
\hline 1,4 & 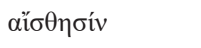 & intellectus & umênie & въдъние & ҮюВЪСТТИЕ \\
\hline 1,9 & 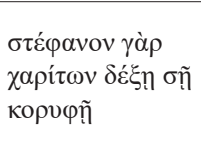 & $\begin{array}{l}\text { ut addatur gratia } \\
\text { capiti tuo }\end{array}$ & $\begin{array}{l}\text { da predast'se } \\
\text { vênacb } \\
\text { bl(a)godêt'ni } \\
\text { gl(a)vê tvoei }\end{array}$ & $\begin{array}{l}\text { АА Придаст сє } \\
\text { вТНЦь БАГОАСТТИ } \\
\text { ГААВЕ ТВОЕИ }\end{array}$ & 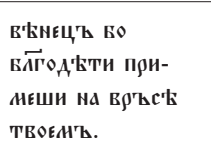 \\
\hline
\end{tabular}

Таблица 4. Разлики между двата бревиара

Table 4. Differences between the two Breviaries

\begin{tabular}{|c|c|c|c|c|c|}
\hline стих & гръцки & латински & Втори берамски & $\begin{array}{c}\text { Първи връб- } \\
\text { нички }\end{array}$ & $\begin{array}{c}\text { кирилски тек- } \\
\text { стове }\end{array}$ \\
\hline 1,3 & 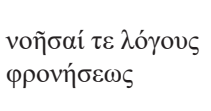 & $\begin{array}{l}\text { ad intellegenda } \\
\text { verba prudentiae }\end{array}$ & $\begin{array}{l}\text { na urazumênie } \\
\operatorname{sl}(\mathrm{o}) \mathrm{v}(\mathrm{e}) \mathrm{sb} \\
\text { premudr(o)sti }\end{array}$ & 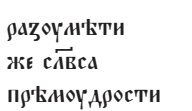 & 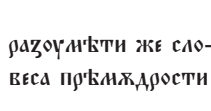 \\
\hline
\end{tabular}




\begin{tabular}{|c|c|c|c|c|c|}
\hline 1,4 & $\pi \alpha v o v \rho \gamma i ́ \alpha$ & astutia & nauka & ковая'ствво & 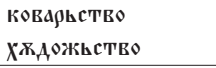 \\
\hline 1,7 & 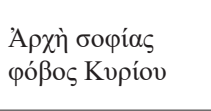 & $\begin{array}{l}\text { Timor Domini } \\
\text { principium } \\
\text { scientiae }\end{array}$ & $\begin{array}{l}\text { strah'že g(o- } \\
\text { spoda)nь začelo } \\
\text { premudrosti }\end{array}$ & 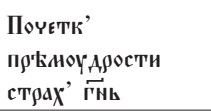 & 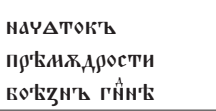 \\
\hline 1,7 & 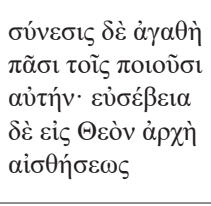 & липсва & $\begin{array}{l}\text { strahь g(ospo- } \\
\text { da)nь načelo } \\
\text { čuv's'tviû }\end{array}$ & 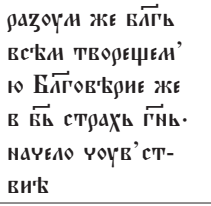 & 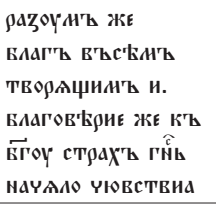 \\
\hline 3,13 & 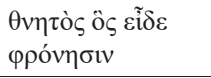 & $\begin{array}{l}\text { qui affluit } \\
\text { prudentia }\end{array}$ & $\begin{array}{l}\text { iže obiluetь } \\
\text { mudrostiû }\end{array}$ & 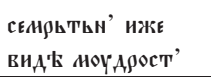 & 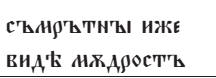 \\
\hline 3,14 & $\dot{\varepsilon} \mu \pi о \rho \varepsilon v ́ \varepsilon \sigma \theta \alpha \iota$ & adquisitio & priiskanie & коүповати & коүповати \\
\hline 3,15 & 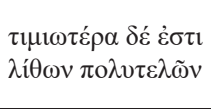 & $\begin{array}{l}\text { fructus eius } \\
\text { pretiosior est } \\
\text { cunctis opibu }\end{array}$ & $\begin{array}{l}\text { plodı ee mno- } \\
\text { gocên'ni e(stь) } \\
\text { vsêhь dêlь }\end{array}$ & 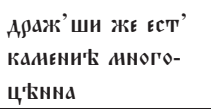 & 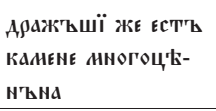 \\
\hline 3,15 & 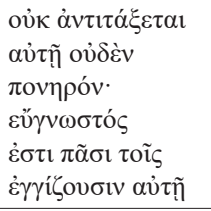 & липсва & липсва & 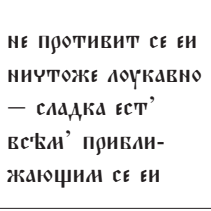 & 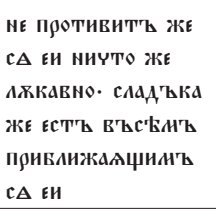 \\
\hline 3,16 & 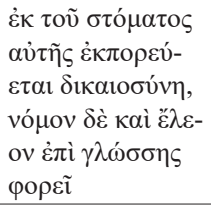 & липсва & липсва & 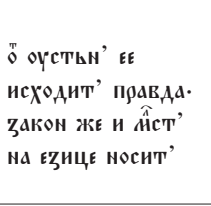 & 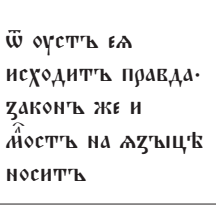 \\
\hline 3,17 & $\kappa \alpha \lambda \alpha i ́$ & pulchrae & krasni & АОБ $\rho и$ & АюБ $\rho и$ \\
\hline 3,17 & 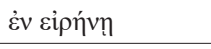 & pacificae & mirni & вь нияФ & в' нирб \\
\hline 3,18 & $\xi \tilde{\lambda} \mathrm{ov} \zeta \omega \tilde{\eta}$ & lignum vitae & drêvo (živo)ta & А९Тво животно & А९СЕВо животно \\
\hline 3,18 & 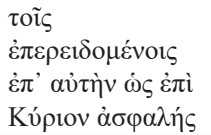 & $\begin{array}{l}\text { qui tenuerit eam } \\
\text { beatus }\end{array}$ & $\begin{array}{l}\text { b(la)ž(e)nь iže } \\
\text { držit' û }\end{array}$ & $\begin{array}{l}\text { и всланаючИА се } \\
\text { на ю ТКО на Га } \\
\text { ТВ } \rho^{\prime} \text { Аа }\end{array}$ & 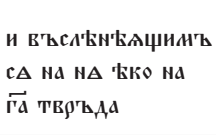 \\
\hline
\end{tabular}

От представения материал се вижда, че Вторият берамски бревиар попада в групата на бревиарите с превод на Притчи Соломонов от гръцки, в които текстът е редактиран с цел изравняване с латинския. Това е групата на Първи и Втори новлянски и Ватиканския Illir. Borg. 5, която съответства на група $\mathrm{A}_{2}$ в класификацията на Чермак. Вижда се, че целта на промените е била текстьт в бревиара да се доближи синтактично и по обем до латинския, като се запази лексиката от Кирило-Методиевия 
превод. Там, където са направени лексикални промени под влияние на латинския текст, обикновено се използва стандартна книжовна лексика, а не се забелязват латинизми нито народни думи. Като народна дума може да се посочи само ûnošica в 1,4. Трябва да се отбележи, че поправките не са правени само в зависимост от латински, а и с цел подобряване на текста. Такава е например замяната на көвдљьство с nauka заради негативното значение, което първата дума е придобила. Замяна в тази посока е направена и в кирилската традиция, като вместо ковдрьство е използвано Ххдожиство.

Тъй като в първото четиво Първият връбнички бревиар на редица места съвпада с Втория берамски и се различава от кирилските текстове, а според данните, приведени от Вайс, съвпада и с Видовия и Пашманския, възниква въпросът дали е имало по-ранен бревиар, който да е следвал изцяло първоначалния превод от гръцки. Както посочва Чермак, цитиран в началото на статията, ръкописите от група В, в които има лексеми, съответстващи на гръцкия текст и отсъстващи във всички ръкописи от група A, показват, че дори и в Бревиара на Вид Омишлянин, който се смята за textus optimus, не се пази най-ранният бревиарен текст на Притчи. И все пак, според източниците, с които разполагаме, е напълно вероятно още в първия бревиар текстът на стария превод да не е бил взет наготово, а да са били внесени промени в посока към изравняване с латинския текст. За това свидетелства и мястото $(1,3)$, където Първият връбнички и Вторият берамски бревиар се различават, но текстът и в двата съответства на израз в латински: na priêtie učeniê nauka срещу и прићти стююєниє оүчєнић за suscipiendam eruditionem doctrinae, докато в гръцки стои съвсем друг

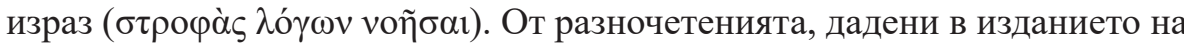
Вайс, се вижда, че тук бревиарите се раделят на същите две групи, както и в случаите, когато разликите в тях се дължат на отношението към грыцкия и латинския текст (VAJS 1910: 50). Затова е много вероятно на това място редакторите да са поправили такъв текст, какъвто се пази в Първия връбнички и Видовия бревиар. Това означава, че вероятно гръцкият текст още в началото е бил частично редактиран за нуждите на бревиара.

Сравнението с Хървоевия мисал показва значителна близост между него и Втория берамски бревиар, като в повечето случаи двата ръкописа съвпадат там, където текстът съответства на латинския. Но в мисала се откриват и следи от стария превод от грьцки - не само в началото на 3:18, където текстьт съответства на текста в Септуагинта, съвпада с Паримейника и се различава от латинския, а и при превода на някои ду- 
ми, които имат еднакво значение в гръцкия и в латинския текст. Много характерен е преводът на бофі́ $\alpha$ - sapientia c premudrostь, която е типична Кирило-Методиева лексема, както и преводът на родителен падеж (в гръцки и латински) с притежателно прилагателно: drěvo život'no, a не

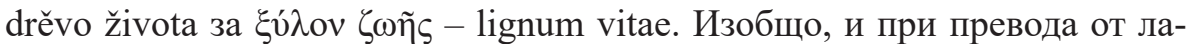
тински в мисала се вижда предпочитанието на традиционната книжовна лексика, наследена от Кирило-Методиевите преводи, което ясно изпъква при сравнението с чешкия текст.

Текстът на Чешката глаголическа библия е даден за фон, на който да се види разликата в превода от латински, а не с цел да бъде анализиран подробно. При сравнението веднага прави впечатление употребата на чешки лексеми като poviest, opatrnost, robat, zprava, počatek, bazen, blazen, nahrdlek, przipliva, nalezenie, prodlenie, pravica, levica, cesta, pokoine, докато хърватският текст се придържа към наследената книжовна лексика. Както посочва Владимир Киас, преводът на Притчи в този ръкопис е по първата редакция на чешкия библейски превод (KYAS 1956: 339; 1997: 43). Първият чешки превод на Библията, осъществен в средета на XIV в. в някой от пражките манастири за монахините, които не са разбирали латински (KYAS 1997: 50), не е еднороден. Киас разделя преводачите на две групи, като в едната влизат книжовници, които се придържат повече към наследената книжовна терминология и употребяват pop за sacerdos (срещу knе̌z при преводачите от втората група), blahoslavený за benedictus (срещу роžehnaný), klaněti sě за orare (срещу modliti sě) (KYAS 1997: 43). Книгата Притчи е сред тези, които са дело на преводачите от първата група, и влиза в Чешката глаголическа библия, без да е редактирана. Йозеф Вайс отбелязва също, че в Чешката глаголическа библия на места се употребява mir в значение 'рах', но по-често се среща pokoj (VAJS 1908: 24). В приведения откъс също намираме pokoine.

Друга особеност на превода, на която обрьща внимание Киас, е това, че преводачите използват една и съща славянска лексема за превод на различни латински (KYAS 1997: 45-46). Това се забелязва и в разгледаните откъси: виждаме, че mudrost съответства както на sapientia, така и на prudentia (в 3,13 и 3,19). При това в 3,13 намираме mudrost и в хърват-

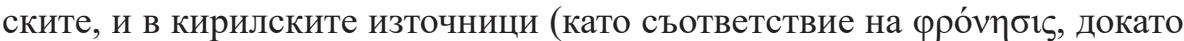
на бофí $\alpha$ съответства premudrost). И на други места лексемите в чешкия превод съвпадат с текста в Първия берамски бревиар: umienie/umêni; krasne/krasni, или в Първия връбнички бревиар и в кирилските ръкописи: dražši/А९dж’ши, или във всички останали славянски източници: rozum/ 
razumb. Това са или думи от общия славянски лексикален фонд, или думи, наследени от книжовната традиция, но не е изключено и хърватско влияние върху чешкия превод. Както посочва Йоханес Райнхарт, между хърватските и чешките книжовници е имало активно сътрудничество и се откриват както бохемизми в хърватските паметници, така и хърватски заемки в чешките (REINHART 1997: 197). Като цяло чешкият превод прави впечатлиние с това, че е ясен, с балансирано използване на стара книжовна и нова чешка лексика, а на места е доста свободен, например при превода на gratia със slava $(1,9)$. Киас характеризира превода така: »Přreklady jsou vesměs poměrně volné, využívají tvárného jazyka rozvíjející se staročeské prózy a snaží se o dobrou srozumitelnost vice než o doslovnost (KYAS 1997: 44). Тази характеристика се отнася напълно и до разгледаните откъси от Притчи Соломонови.

\section{ИЗВОРИ}

1. Септуагинта - Използвана е по изданието RAHLFS 1935.

2. Вулгата - Използвана е по изданието WEBER; GRYSON 2007.

3. Втори берамски бревиар. Глаголически рькопис от XV в. Използван е по изданието BADURINA STIPČEVIĆ, V. i dr. 2018.

4. Първи връбнички бревиар - глаголически ръкопис от края на XIII - началото на XIV в. Използван е по VAJS 1910: 40-49.

5. Хървоев мисал - глаголически ръкопис от началото на XV в. - използван е по изданието GRABAR; NAZOR; PANTELIĆ 1973. Четивото от Притчи 3,13-19 е на с. 387.

6. Чешка глаголическа библия (Вишебродска библия) - глаголически ръкопис от 1416 г., създаден в Емауския манастир в Прага - използвана е по изданието РАСNEROVÁ 2000. Четивата Притчи 1,1-9 и 3,13-20 са на с. 262 и 264.

7. Григоровичев паримейник - кирилски ръкопис от XII в. - използван е по изданиеTo RIBAROVA; HAUPTOVÁ 1999.

8. Ръкопис от Руската национална библиотека в Санкт Петербург, сигн. F.I.461 Кирилски ръкопис от XIV в. - Използван е по микрофилм.

9. Острожка печатна библия от 1581 г. - Използвана е по изданието Острожская библия 1988.

\section{ЛИТЕРАТУРА}

ALEKSEEV, А. 1999 = АЛЕКСЕЕВ, А. 1999. Текстология славянской Библии. Санкт-Петербург: Издательство Дмитрия Буланина. [ALEKSEEV, A. 1999. Tekstologija slavjanskoj Biblii. Sankt-Peterburg: Dmitrij Bulanin Publishing House]. 
BADURINA STIPČEVIĆ, V. i dr. 2018 = BADURINA STIPČEVIĆ, V; I. BOTICA; M. DIMITROVA; M.-A. DÜRRIGL; I. HRISTOVA ŠOMOVA; K. KUHAR; M. MIHALJEVIĆ; S. POŽAR; A. RADOŠEVIĆ; A. ŠIMIĆ; M. ŠIMIĆ; J. VELA; J. VINCE; J. VUČKOVIĆ; S. ZUBČIĆ; M. ŽAGAR. Drugi beramski brevijar: hrvatskoglagoljski rukopis 15. stoljeća, 1. dio, sv. 2: transliteracija. M. Mihaljević (prir.). Zagreb: Staroslavenski institut.

BRANDT, R. 1894 = БРАНДТ, Р. Григоровичев паримейник в сличении с другими паримейниками. Москва: Университетская типография. [BRANDT, R. Grigorovičev parimejnik v sličenii s drugimi parimejnikami. Moskva: Universitetskaja tipografija].

ČERMÁK, V. 1999. Proverbia v charvátskohlaholských breviářích a jejich neslovanské předlohy. Slavia 68: 251-258.

ČERMÁK, V. 2003. Význam charvátskohlaholských pramenů pro výzkum slovanského překladu starozákonních knih. I. Pospišíl; M. Zelenka (ed.) Česká slavistika 2003. České přednášky pro XIII. mezinárodní kongres slavistů. Ljubljana 15. - 21. 8. 2003. Praha: Academia, 59-69.

ČERMÁK 2007. = ЧЕРМАК, В. 2007. К некоторым особеностям членения славянского перевода Книги Притч в рукописи F.I.461. Кирило-Методиевски студии 17: 827-831. [ČERMAK, V. 2007. K nekotorym osobenost'am členenija slav'anskogo perevoda Knigi Pritč v rukopisi F.I.461. Kirilo-Metodievski studii 17: 827-831].

GRABAR, B.; A. NAZOR; M. PANTELIĆ. 1973. Hrvatskoglagoljski misal Hrvoja Vukčića Hrvatinića: Transkripcija i komentar. Zagreb - Ljubljana - Graz: Staroslavenski institut »Svetozar Ritig« - Mladinska knjiga - Akademische Druck- und Verlangsantstalt.

KYAS, V. 1956. Česká Hlaholská bible v poměru k ostatním českým biblickým rukopisům. Slavia 25: 328-341.

KYAS, V. 1997. Česká bible v dějinách národního písemnictví. Praha: Nakladatelství Vyšehrad.

PACNEROVÁ, L. 2000. Česká Bible hlaholská (Bible Vyšebrodská). Praha: Slovanský ústav. Nakladatelství Euroslavica.

RAHLFS, A. 1935. Septuaginta. Id est Vetus testamentum graece iuxta LXX. Interpretes edidit A. Rahlfs. Stuttgart: Priviligierte Württembergische Bibelanstalt.

REINHART, J. 1986: The Sapiential Collection in the Croatian Glagolitic Missal. Ninth World Congress of Jewish Studies. Division D. Vol. 1. Jerusalem: World Union of Jewish Studies, 77-84.

REINHART, J. 1997. Zwischenslavische Übersetzungen im Mittelalter. Wiener slavistisches Jahrbuch 43: 189-203.

RIBAROVA, Z.; Z. НAUPTOVÁ. 1999. = РИБАРОВА 3.; 3. ХАУПТОВА. 1999. Григоровичев паримејник, Скопје: МАHУ. [RIBAROVA, Z.; Z. HAUPTOVÁ. 1999. Grigorovičev parimejnik, Skopje: MANU].

SLOVNÍK 1959 = Slovník jazyka staroslověnského, I: a-gerv. J. Kurz (ed.). Praha: Academia, nakladatelství Československé akademie věd.

THOMSON, F. 1998. The Slavonic Translation of the Old Testament. J. Krašovec (ed.). Interpretation of the Bible. Ljubljana - Sheffield: Slovenska akademija znanosti i umetnosti - Shefield Academic Press, 605-920. 
VAJS, J. 1908: Česká Bible hlaholská. Praha: Nákladem Královské české společnosti náuk.

VAJS, J. 1910. Nestarši breviář chrvatsko-hlaholský (Prvý breviár vrbnický): úvodem a bibliografickými popisy hlaholských breviářù starši doby opatřil.). Praha: Nákladem Královské české společnosti náuk.

WEBER, R.; R. GRYSON 2007. Biblia Sacra iuxta vulgatam versionem. R. Weber; R. Gryson (ed.). Stuttgart: Deutsche Bibelgesellschaft.

Острожская библия. 1988. Фототипическое переиздание текста с издания 1581 года. Москва - Ленинград: Слово-Арт. [Ostrožskaja biblija. Fototipičeskoe pereizdanie teksta s izdanija 1581 goda. Moskva - Leningrad: Slovo-Art].

\section{ПРИЛОЖЕНИЕ 1: ПРИТЧИ СОЛОМОНОВИ 1,1-9}

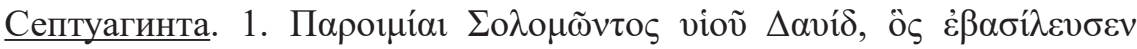

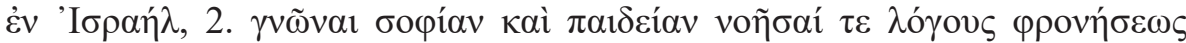

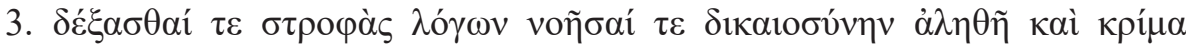

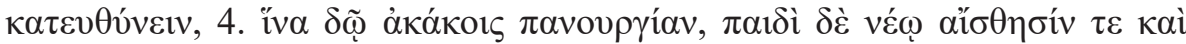

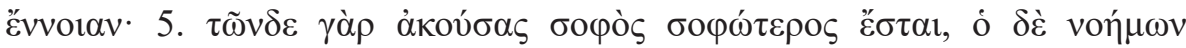

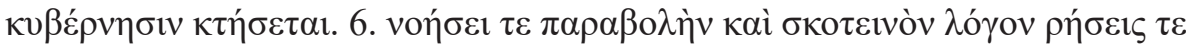

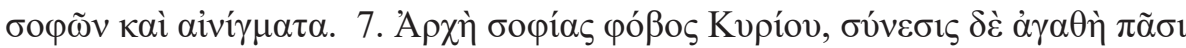

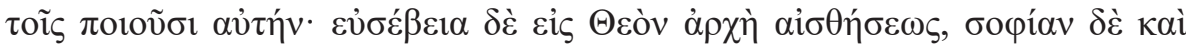

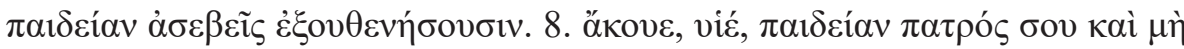

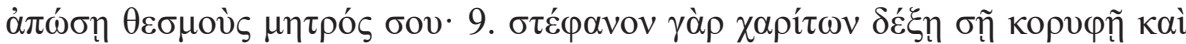

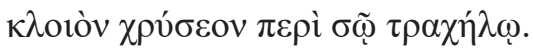

Вулгата. 1. Parabolae Salomonis filii David regis Israhel 2. ad sciendam sapientiam et disciplinam 3. ad intellegenda verba prudentiae et suscipiendam eruditionem doctrinae iustitiam et iudicium et aequitatem 4 . ut detur parvulis astutia adulescenti scientia et intellectus. 5. Audiens sapiens sapientior erit et intellegens gubernacula possidebit. 6. Animadvertet parabolam et interpretationem verba sapientium et enigmata eorum. 7. Timor Domini principium scientiae sapientiam atque doctrinam stulti despiciunt. 8. Audi fili mi disciplinam patris tui et ne dimittas legem matris tuae. 9. Ut addatur gratia capiti tuo et torques collo tuo.

Втори берамски бревиар, л. 230b-c. 1. Prit’če salomuna s(i)na d(a)v(i)d(o)va c(êsa)ra iz(drai)l(e)va. 2. na poznanie premudr(o)sti i nakazanie. 3. na urazumênie $\mathrm{sl}(\mathrm{o}) \mathrm{v}(\mathrm{e}) \mathrm{ss}$ premudr(o)sti. na priêtie učeniê nauka pr(a)vdi i suda. 
i pravosti 4. da dast' se ml(a)dên'cemb naukb i ûnošicamb umênie i razumb. 5. sihь slišavb mudarb. mudrêi budet' i razumêv' e stroeniemь obladaetb. 6 . $d(u)$ šev'nuû obratits prit'ču. i t'lmačenie $\operatorname{sl}(\mathrm{o}) \mathrm{v}(\mathrm{e})$ sa prem(u)dr(o)sti i gananiê ihь. 7. razum' že blagь tvoreĉim' û. bl(a)govêrie v' (!) že v' b(og)ь. strahь g(ospoda)nь načelo čuv's'tviû. strah' že g(ospoda)nь začelo premudrosti. premudrosti i naučenie brez'um'ni nenavidetb. 8. sliši s(i)nu moi. nakazanie o(t)ca tvoego. i ne otpucaai zakona matere tvoee. 9. da predast' se vênacь bl(a)godêt'ni gl(a)vê tvoei i griv'na zlata šii tvoei.

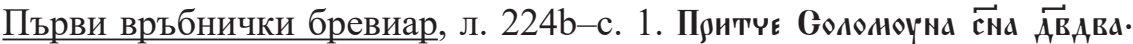

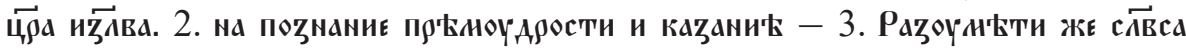

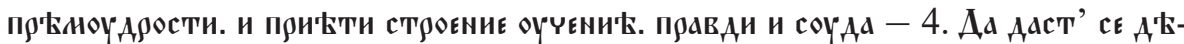

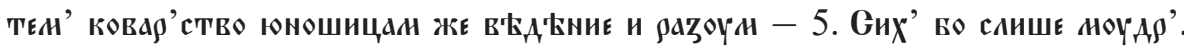

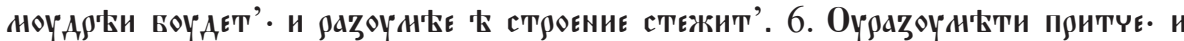

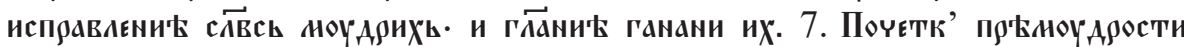

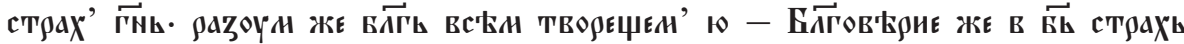

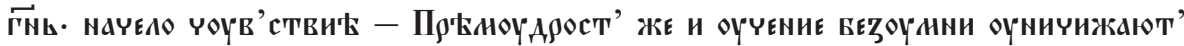

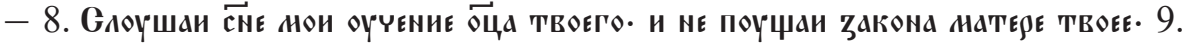

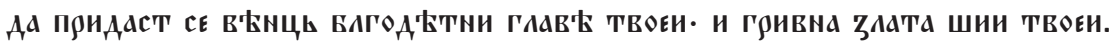

Хървоев мисал. Това четиво липсва в Хървоевия мисал.

Чешка глаголическа библия, л. 130ba. 1. Povies’ti šalomunovi. s̆a dda krale izrahel'skeho. 2. k umieni mudrosti i kazni. 3. k urozumieni slov' opatrnosti. a k przijeti umielěho naučenie. spravedlivosti i suda. i pravosti. 4. Abi bila dana robatom' opatrnost'. a jinochu umienie a rozum'. 5. Usliši e mudri. mudrzieji bude. a rozumni zpravami vlasti bude. 6 . Znamenaite poviest' i viklad'. slova mudrich i jich' znamenanie. 7. Bazen bžie. počatek' mudrosti. Mudrosti a učenim'. blaznově hr'daji. 8. Posluchai șu moi kaznie otce tveho. a ně ostavai Zkna matěrze tvě. 9. at' bude dana sTva hlavie tvě a nahr'dlek' šiji tvěi.

Григоровичев паримейник, л. 14v-15r. 1. ПрнттъчА сононона $: \overrightarrow{\mathrm{cHa}} \overrightarrow{\mathrm{AB}}$ Еже ЦҺ

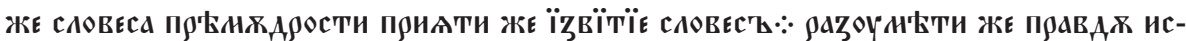

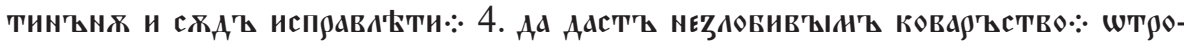

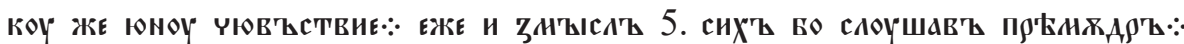

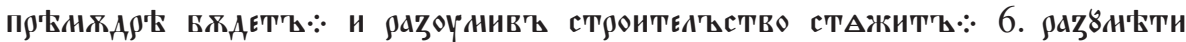

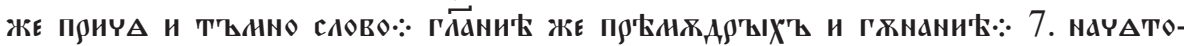




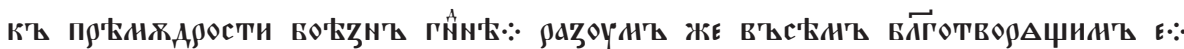
БДГОВТ

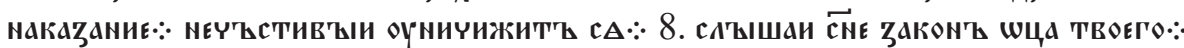

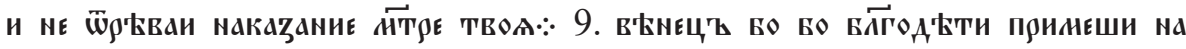

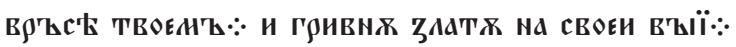

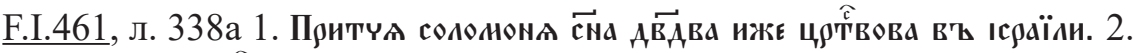

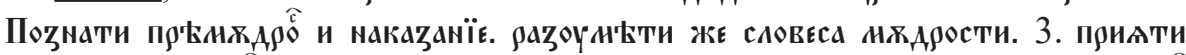
Же иъвитї̈ слове

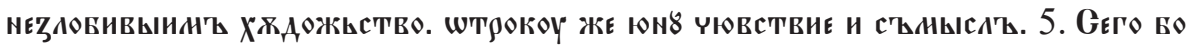

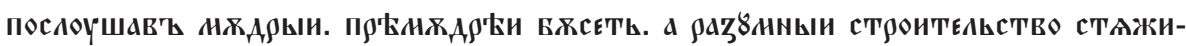

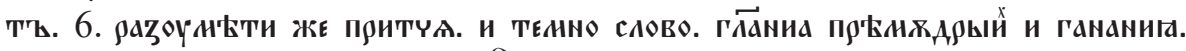

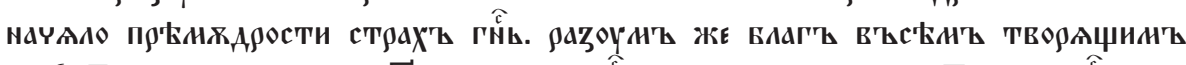

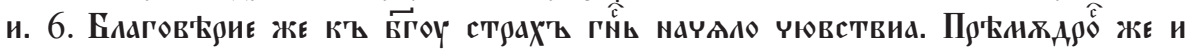

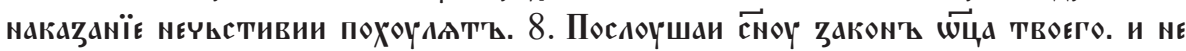

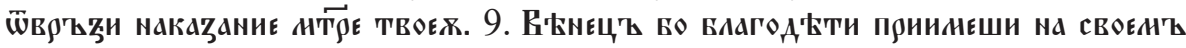

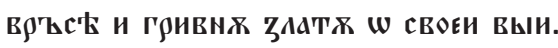

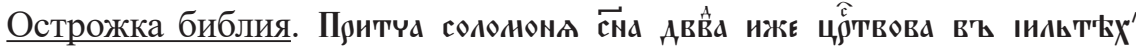

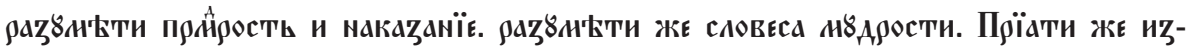

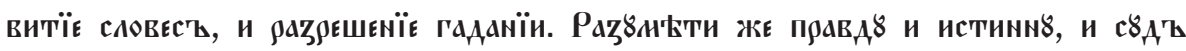

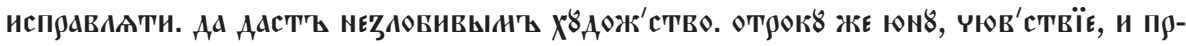

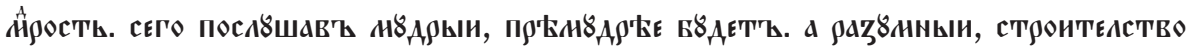

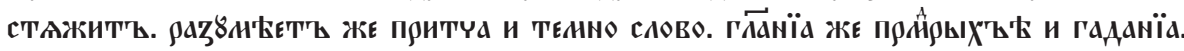

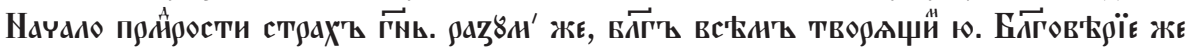

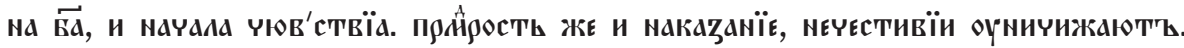

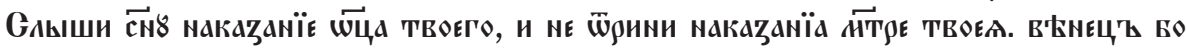

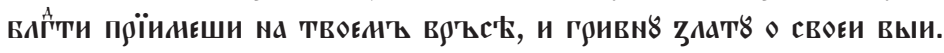

\section{ПРИЛОЖЕНИЕ 2: ПРИТЧИ СОЛОМОНОВИ 3,13-20}

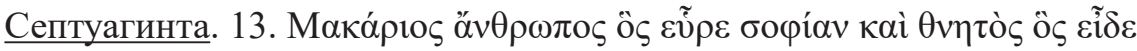

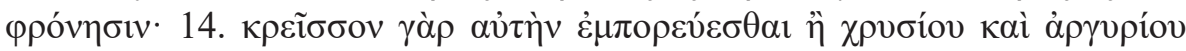

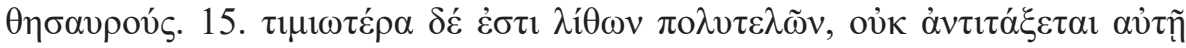

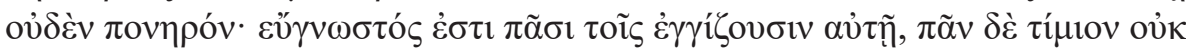

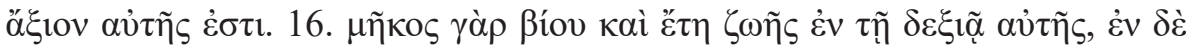

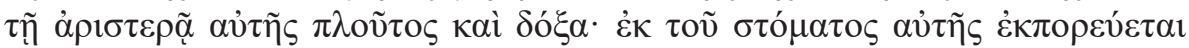




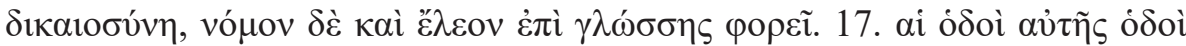

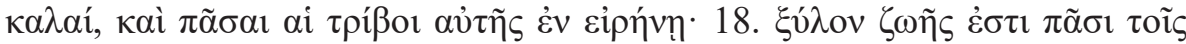

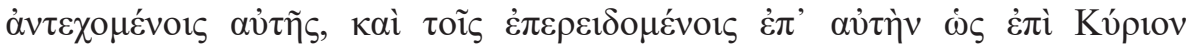

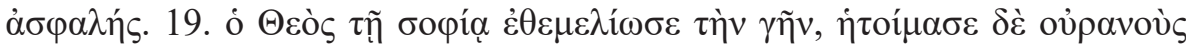

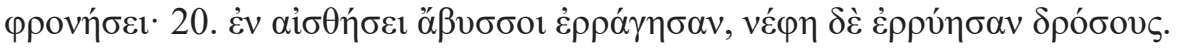

Вулгата. 13. Beatus homo qui invenit sapientiam et qui affluit prudentia. 14. Melior est adquisitio eius negotiatione argenti et auro primo fructus eius. 15. Pretiosior est cunctis opibus et omnia quae desiderantur huic non valent conparari. 16. Longitudo dierum in dextera eius in sinistra illius divitiae et gloria. 17. Viae eius viae pulchrae et omnes semitae illius pacificae. 18. Lignum vitae est his qui adprehenderint eam et qui tenuerit eam beatus. 19. Dominus sapientia fundavit terram stabilivit caelos prudentia. 20. Sapientia illius eruperunt abyssi et nubes rore concrescunt.

Втори берамски бревиар, л. 232b. 13. b(la)ž(e)nь č(lovê)kь iže obrêcetь mudrosti. i iže obiluetb mudrostiû. 14. luč'še e(stb) priiskanie pače s'rebra $i$ zlata pravago i prečistago 15. plodь ee mnogocên'ni e(stb) vsêhb dêlı. i vsa želêtel'na netakmena ei. 16. dlgota bo dni v dêsnicê ee. i v' šuicê ee bogatastvo i sl(a)va. 17. puti ee puti kras'ni. i vse stazi ee mirni. 18. drêvo (živo)ta e(stb) vsêmь dr'žeĉim' û. b(la)ž(e)nь iže držit' û. 19. g(ospod)ь osnova mudrostiû z(e)mlû. i utvr'di neb(e)sa razumomb. 20. mudros't' ego prorazi. i oblaci potočiše rosi.

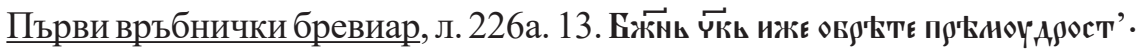

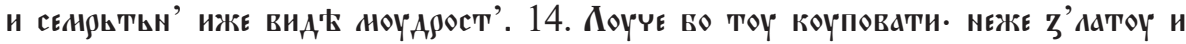

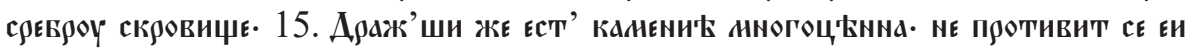

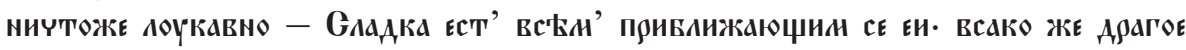

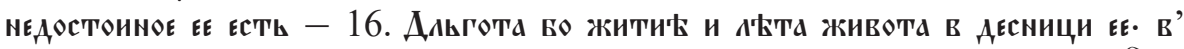

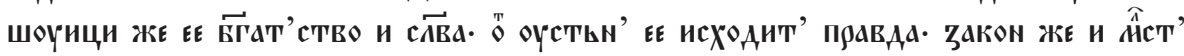

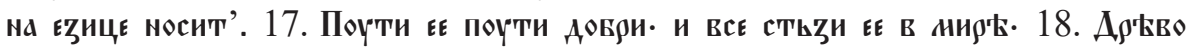

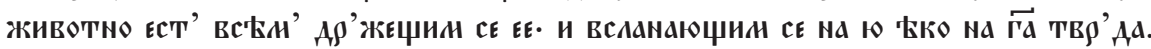

Хървоев мисал, л. 194ab. B(la)ž(e)nь č(lově)kь. ki naidetь mudrostь. i ki obiluet' mudrostiju. 14. bol'še e(stb) preiskanie ego pače zlata i srebra pravago i prečistago 15. Plod' ego mnogocěnanb e(stb). pače vsačaskihь dělb. i vsa ka vželějut' se něsutb takmena ei. 16. Dl'gota bo d(b)ni v desnici ee. i v' šuici ee bogatastvo i sl(a)va. 17. Blaga e(stb) vsěmb blizb ee budučimь. i vsako dra- 
go něstb takmeno ei. Puti ee krasni. i vse stazi ee mir'ni. 18. Drěvo život'no e(stь) vsim' pridržećimь se еe (Рочки мисал: + i iže dr’žetь ju). 19. g(ospod)ь premudrostiju osnova $z(e) m l j u$. utvrdi $n(e) b(e) s a$ razumomь. 20. Mudrostb ego otvrze bezdni. i oblaci vzrastut rosoju.

Чешка глаголическа библия, л. $131 \mathrm{~b} \alpha-\beta .13$. Blaženi čks. enž est nalezl' smisl' a emuž przipliva mudrost'. 14. Neb' est lepšie ejie nalezenie. než strziebra ani zlata. a prvnieho. i przečisteho. 15. Užitekb ejie dražši est nade vše zbožie. a všecko ehož' dše žada. nemož se jie przirovnati. 16. Prodlenie ejie dnov'. a ejie pravici. na ejie levici. bohatstvie a slava. 17. Cesti ejie cesti krasne. a všecki stezi ejie pokoine. 18. Drzevo viečneho života est tiem' ktož ji popadne. 19. Gdins smislem založil' est zemi. ustanovil est n̋ssa mudrosti. 20. Mudrosti eho virzinuli jsu propasti a oblaci rosu se srostuji.

Григоровичев паримейник, л. 20rv, 22r. Блажєн'ъ ч

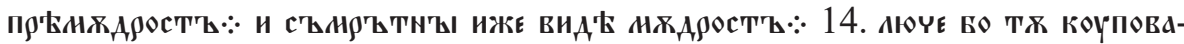

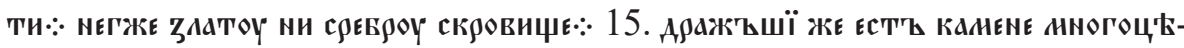

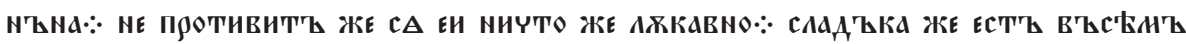

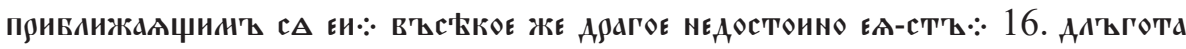

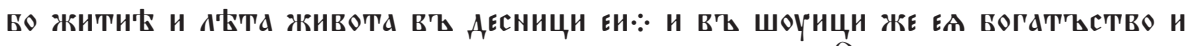

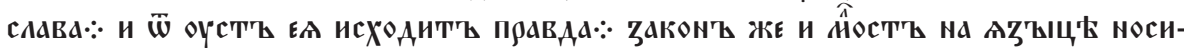

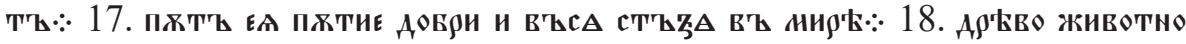

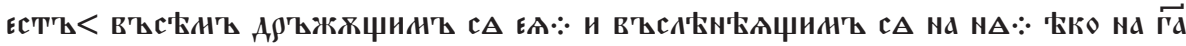

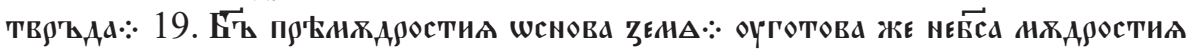

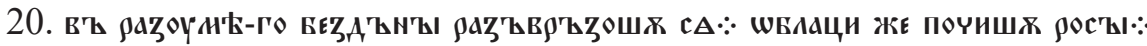

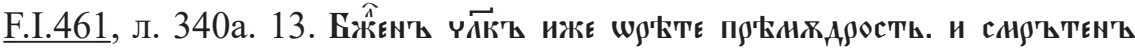

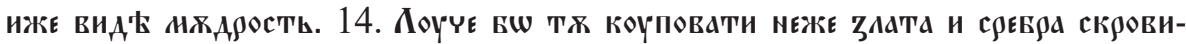

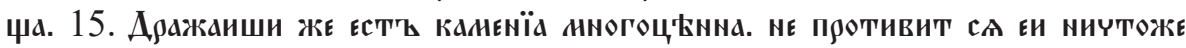

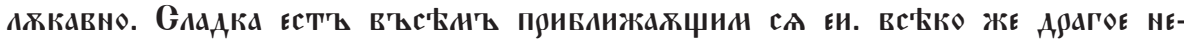

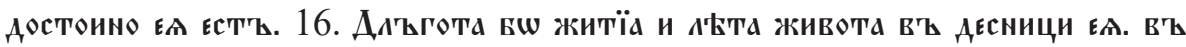

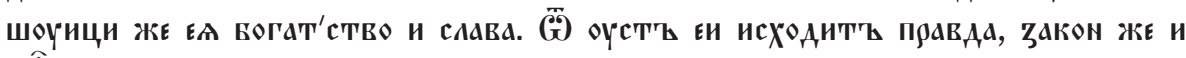

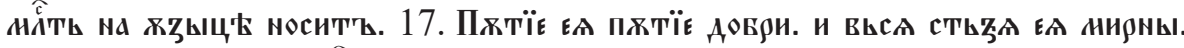

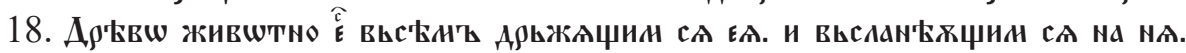

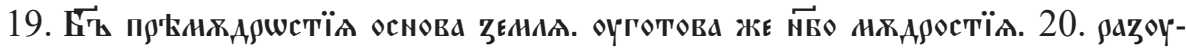

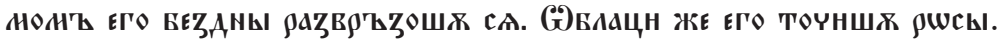

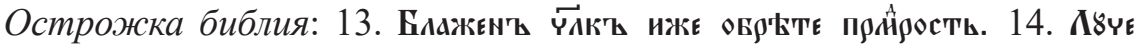

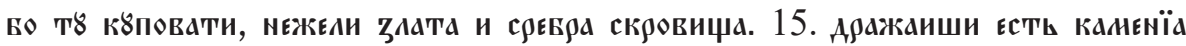




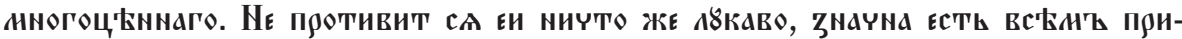

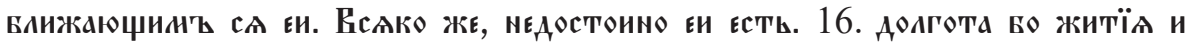

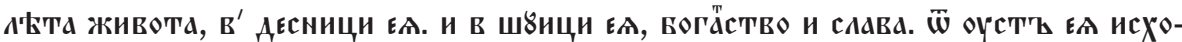

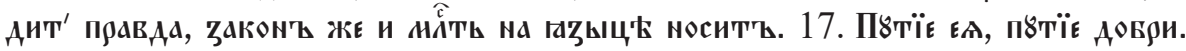

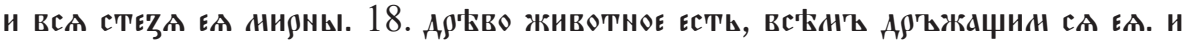

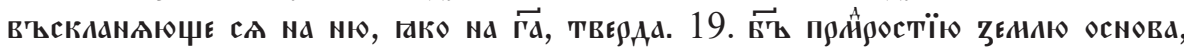

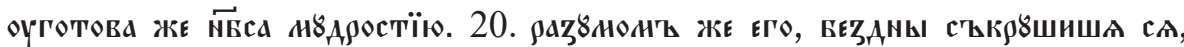
ОБАаЦЫ Же Поточиша ९осы.

\section{Summary}

\section{Iskra HRISTOVA SHOMOVA}

\section{THE BOOK OF PROVERBS IN THE SECOND BERAM BREVIARY}

The article discusses the texts of two readings of the Book of Proverbs $(1,1-9$ and 3,13-20) in the Second Beram Breviary. They have been compared with six other medieval Slavonic texts, three Glagolitic and three Cyrillic: the First Vrbnik Breviary from the $12^{\text {th }}-13^{\text {th }}$ century, the Hrvoje's Missal from the beginning of the $15^{\text {th }}$ century, the Czech Glagolitic Bible from 1416 , the Grigorovich Parimejnik from the $12^{\text {th }}$ century, the manuscript from the Russian National Library F.I.461 from the $14^{\text {th }}$ century and the Ostrog Bible from 1591. The comparison shows that there are differences between the Greek and the Latin text, at the syntactic as well as at the lexical level. In the first lecture, both Croatian Breviaries most often follow the syntax of the Latin text, but they preserve the ancient Cyrillo-Methodian vocabulary. In the second lecture there are more differences between the Breviaries. The First Vrbnik Breviary follows the Greek text and is nearly identical with the Cyrillic texts, while the Second Beram Breviary, as well as the Hrvoje's Missal, contains a text, which is closer to the Latin text at the syntactic level, but usually preserves the Cyrillo-Methodian lexemes. It is significant that these two Croatian books (the Second Beram Breviary and the Hrvoje's Missal) contain texts, which are so close to each other. The three Cyrillic texts are nearly identical, they reproduce the Greek text and are evidently successors of an ancient translation, most probably, the one of SS. Cyrill and Methodius. The Czech translation follows the Latin text and it contains some typically Czech lexemes (opatrnost, robat, zprava, počatek, bazen, blazen, nahrdlek, nalezenie, prodlenie, pravica, levica, cesta, pokoine).

Key words: Proverbs, Breviary, Missal, Bible, translation, revision.

Iskra HRISTOVA SHOMOVA

Sofia University »St. Kliment Ohridski«

Sofia (Bulgaria)

iskrashomova@gmail.com 